BNWL-653

3-

\title{
DETERMINATION OF RELATIVE BURNUP BY GAMMA SCANNING EBWR FUEL RODS
}

D. E. Christensen

E. S. Murphy

April 1968

\section{AEC RESEARCH \& DEVELOPMENT REPORT}

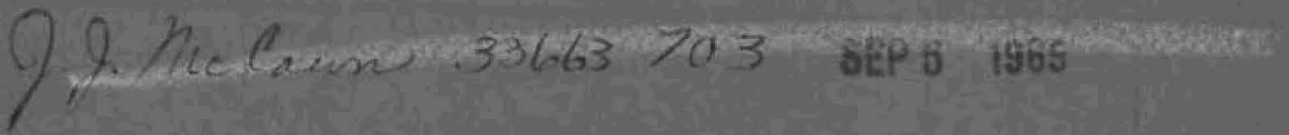




\section{LEGAL NOTICE}

This report was prepored as an cecount of Government sponsored work. Neither the United Stares, nor the Commission, nor any person acting on behalf of the Commission:

A. Makes any warranty or representation, expressed or implied, with respect to the accuracy, com: pleteness, or usefulness of the information contained in this report, or that the use of any information; opparalus, method, or process disclosed in this repart may not infringe privately owned rights; or

B. Assumes any liabilities with respect to the use of, or for damages resulting from the use of any information, apparatus, method, or process disclosed in this report.

As used in the above, "person acting on behalf of the Commission" includes any emplayee or contractor of the Commission, or employee of such contractor, to the extent that such employee or contractor of the Commission, or employee of such contractor prepares, disseminates, or provides access to, any information pursuant to his employment of contracs with the Commission, or his employment with such controctor.

\section{PACIFIC NORTHWEST LABORATORY}

RICHLAND, WASHINGTON

operated by

BATTELLE MEMORIAL INSTITUTE

for the

$s$

UNITED STATES ATOMIC ENERGY COMMISSION UNDER CONTRACT AT(45-1)-1830 


\author{
BNWL -653 \\ UC -80 , Reactor Technology
}

DETERMINATION OF RELATIVE BURNUP

BY GAMMA SCANNING EBWR FUEL RODS

By

D. E. Christensen and E. S. Murphy*

Light Moderator Reactor Physics Section Reactor Physics Department

Apri1 1968

* Dr. E. S. Murphy, presently with the Physics Department, Central Washington State College, Ellensburg, Washington

PACIFIC NORTHWEST LABORATORY

RICHLAND, WASHINGTON 
Printed in the United States of America Available from

Clearinghouse for Federal Scientific and Technical Information National Bureau of Standards, U.S. Department of Commerce Springfield, Virginia 22151

Price: Printed Copy $\$ 3.00 ;$ Microfiche $\$ 0.65$ 


\section{TABLE OF CONTENTS}

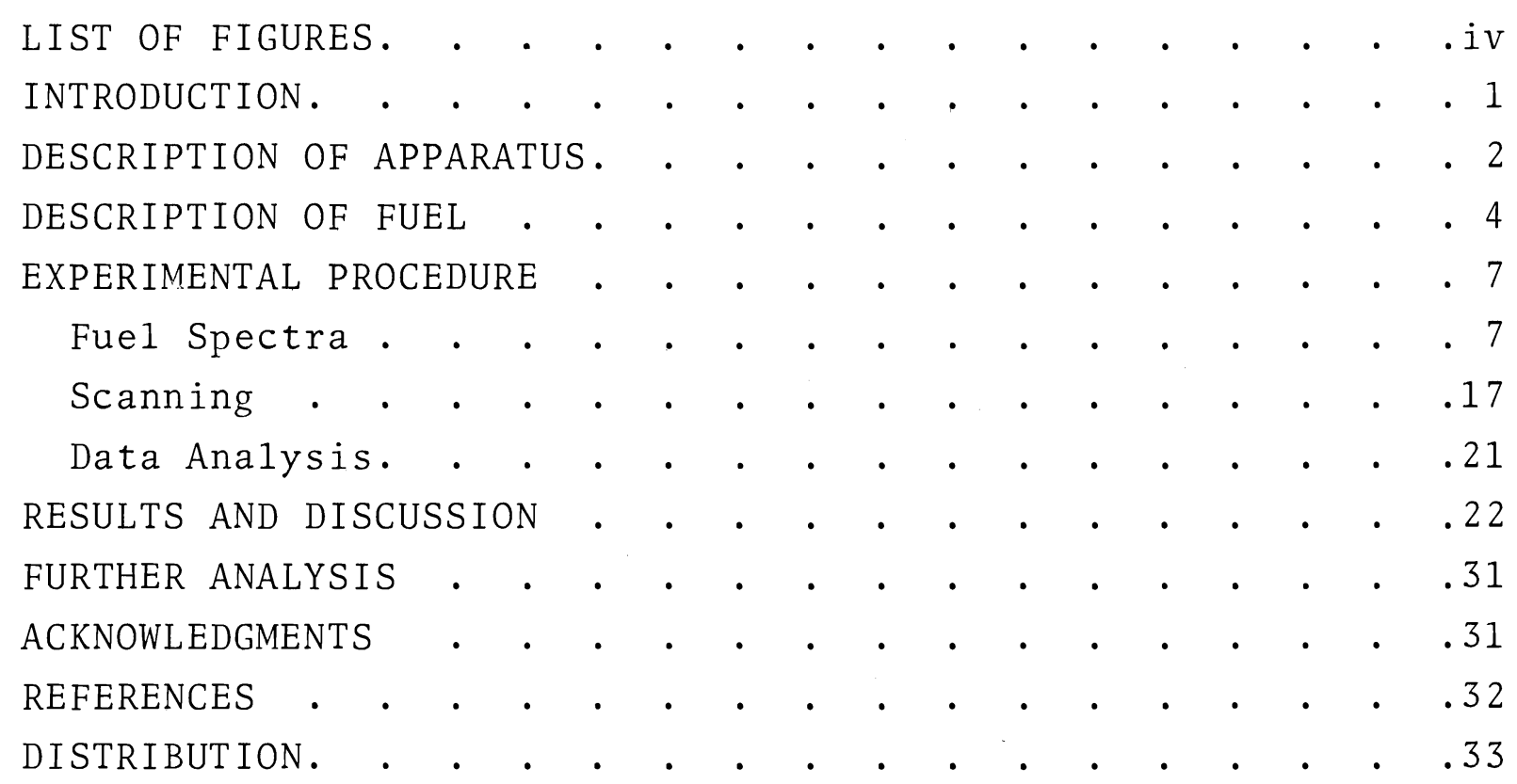




\section{LIST OF FIGURES}

1 Gamma Scan Facility at the PRTR Storage Basin 3

$2 \quad$ Plutonium Region of the EBWR Core 5

3 EBWR UO2-1.5 wt\% PuO2 Fuel Rod and Fuel

Element Basket

3

$4 \quad$ Zone 1 of EBWR Core Showing Positions of

17 Rods that Were Gamma Scanned

Gamma Ray Spectrum of a Mixed Oxide Rod Taken with a Sodium Iodide Detector

Gamma Ray Spectrum of an Al-Pu Rod Taken with a Sodium Iodide Detector

7 Gamma Ray Spectrum of a Natural UO2 Rod Taken with a Sodium Iodide Detector

Gamma Ray Spectrum of a Mixed Oxide Rod Taken with a Ge(Li) Detector

9 Gamma Ray Spectrum of an Al-Pu Rod Taken with a Ge(Li) Detector

10 Gamma Ray Spectrum of a Natural UO2 Rod Taken with a Ge(Li) Detector

11 Comparison of Gamma Scan Data for Rod Number 1

Using Two Different Energy Intervals

Comparison of Gamma Scan Data for Rod Number 15

Using Two Different Energy Intervals

Gamma Scan of a Typical Fuel Rod

Gamma Scans of Radial Rods

Gamma Scans of Fuel Rods Numbers 1, 11, 7, 12, and 10 


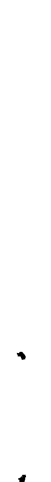

8 


\section{DETERMINATION OF RELATIVE BURNUP \\ BY GAMMA SCANNING EBWR FUEL RODS \\ D. E. Christensen and E. S. Murphy}

\section{INTRODUCTION}

A set of 17 fuel rods from the Experimental Boiling Water Reactor (EBWR) at the Argonne National Laboratory (ANL) has been gamma scanned at the Pacific Northwest Laboratory (PNL). The intensity of the unresolved fuel rod gamma ray spectrum above $675 \mathrm{keV}$ was measured at several points along each rod in order to determine the relative fuel burnup and core power distribution. The measurements are part of a plutonium experiment being performed as a joint program between Pacific Northwest Laboratory and Argonne National Laboratory to demonstrate the utilization of plutonium in a light water-moderated power reactor. $(1,2)$ The National Committee for Nuclear Energy (CNEN) of Italy is also participating in the experiment through a contract with the AEC.

Reactor fuel burnup can be determined by a number of techniques. Most of these involve destruction of a fuel element and radiochemical or mass spectrographic analysis of its contents. Because of the disadvantages of destructive methods, nondestructive techniques have been developed to determine the irradiation history of fuel elements. One of the first reported attempts to obtain fuel burnup data by studying the gamma spectra of fission products with NaI scintillation crystals was made by Kristiansen and Rogeberg. (3) Diggle and Blackadder (4) have summarized results obtained by gamma scanning reactor fuel elements with NaI(T1) detectors.

Recently a number of investigators have initiated work on gamma scanning of fuel elements using solid state Ge(Li) detectors. $(5,6,7,8)$ The superior resolution of these detectors over 
NaI(T1) scintillation crystals, by allowing the investigator to resolve individual gamma ray components in complex fuel rod spectra, has facilitated the absolute determination of fission product activities and, in turn, the absolute determination of fuel burnup.

In the present experiment, both a sodium iodide detector and a germanium detector were employed for gamma scan measurements. The primary objective was to determine the relative burnup distribution in the fuel pins and, therefore, the sodium iodide detector was used to do most of the work. Because sodium iodide has a much higher detection efficiency than do solid state detectors, shorter counting times can be employed. The poorer resolution of sodium iodide, however, does not lend itself to the absolute determination of fission product activities, and the germanium detector was used to take gamma ray spectra as a preliminary step in this direction. The bulk of the data to be presented, therefore, are relative burnup measurements obtained by gamma scanning with a sodium iodide detector. Gamma ray spectra of certain fuel rods have been obtained with a Ge(Li) detector and are included in this report.

\section{DESCRIPTION OF APPARATUS}

The Pacific Northwest Laboratory gamma scan facility is located in the Plutonium Recycle Test Reactor (PRTR) fuel storage basin. The facility permits the scanning of reactor fuel rods shielded by several feet of water. For the EBWR rod scans, a $6 \mathrm{ft}$ shield of water was employed. A diagram of the facility is shown in Figure 1. Collimation of the beam of gamma rays coming from a fuel rod is achieved by two 6-in. sections of lead, one directly above the rod being scanned and the other directly underneath the detector. For this experiment, both collimator sections employed 1/4-in. circular apertures. A shutter above the bottom collimator section can be closed to permit the determination of background. 


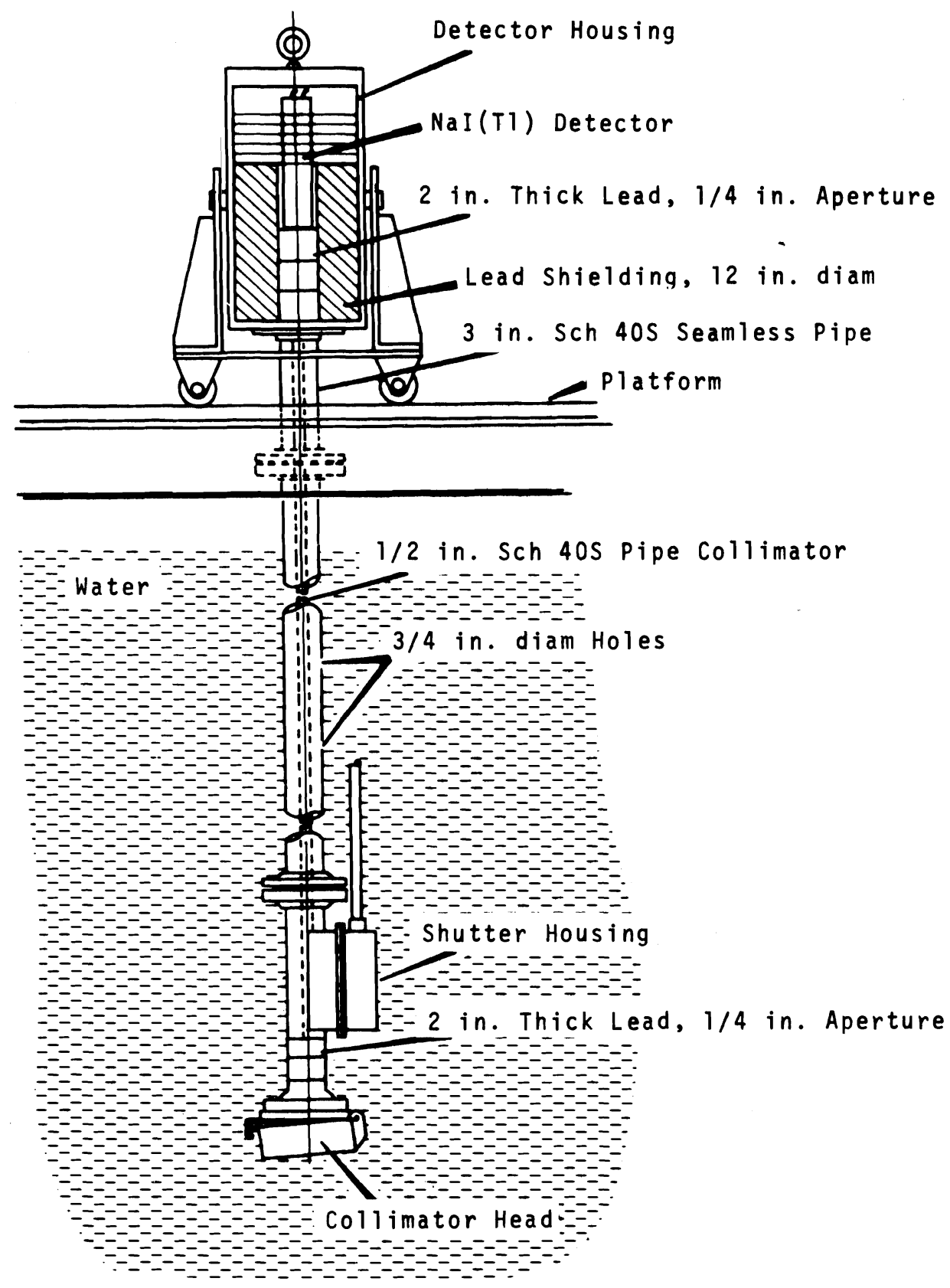

FIGURE 1. Gamma Scan Facility at the PRTR Storage Basin 
The detector, a 2 in. by 2 in. NaI(T1) crystal was optically coupled to an RCA type 6655A photomultiplier tube. The detector was surrounded by $41 / 2$ in. of lead shielding. An opening in the detector shielding permitted insertion of gamma ray sources for calibration purposes. Resolution of the detecting system was $10 \%$ for the $662 \mathrm{keV}$ gamma ray from ${ }^{137} \mathrm{Cs}$.

Pulses from the detector were amplified and analyzed by means of a type DD-2 linear amplifier and single-channel analyzer. The pulses from the single channel analyzer were then counted on a scaler. One-minute counts were taken at each rod position. Additional electronic equipment available at the facility included a count rate meter and chart recorder, and a 512 -channel analyzer for recording gamma ray spectra.

The fuel rod was held stationary and scanned by the scanner moving along a pair of rails. The position of the scanner was indicated by a pointer moving along a steel tape. Positioning was accurate to $\pm 1 / 32$ in.

\section{DESCRIPTION OF FUEL}

The fuel rods employed for gamma scanning were taken from the plutonium region, indicated by the open tube region of Figure 2, of the EBWR core. Sets comprising 17 rods from each quadrant of the plutonium region were selected for analysis at varying increments of burnup. Drawings of a fuel rod and of a fuel element are shown in Figure 3 . (9) The normal rods in the plutonium region were Zircaloy clad, vibrationally compacted $\mathrm{UO}_{2}-1.5$ wt $\% \mathrm{PuO}_{2}$ fuel rods. The uranium was 0.165 at.\% $2355_{U}(10)$ and the plutonium was 8.0 at. $\%{ }^{240} \mathrm{Pu}$. The central fuel element of each quadrant contained five special rods consisting of one natural $\mathrm{UO}_{2}$ fuel rod, two A1-3.35 wt\% $\mathrm{Pu}$ rods in which the atom percent of $240 \mathrm{Pu}$ was approximately $8 \%$ in one rod and approximately $26 \%$ in the other, 
EBWR CORE

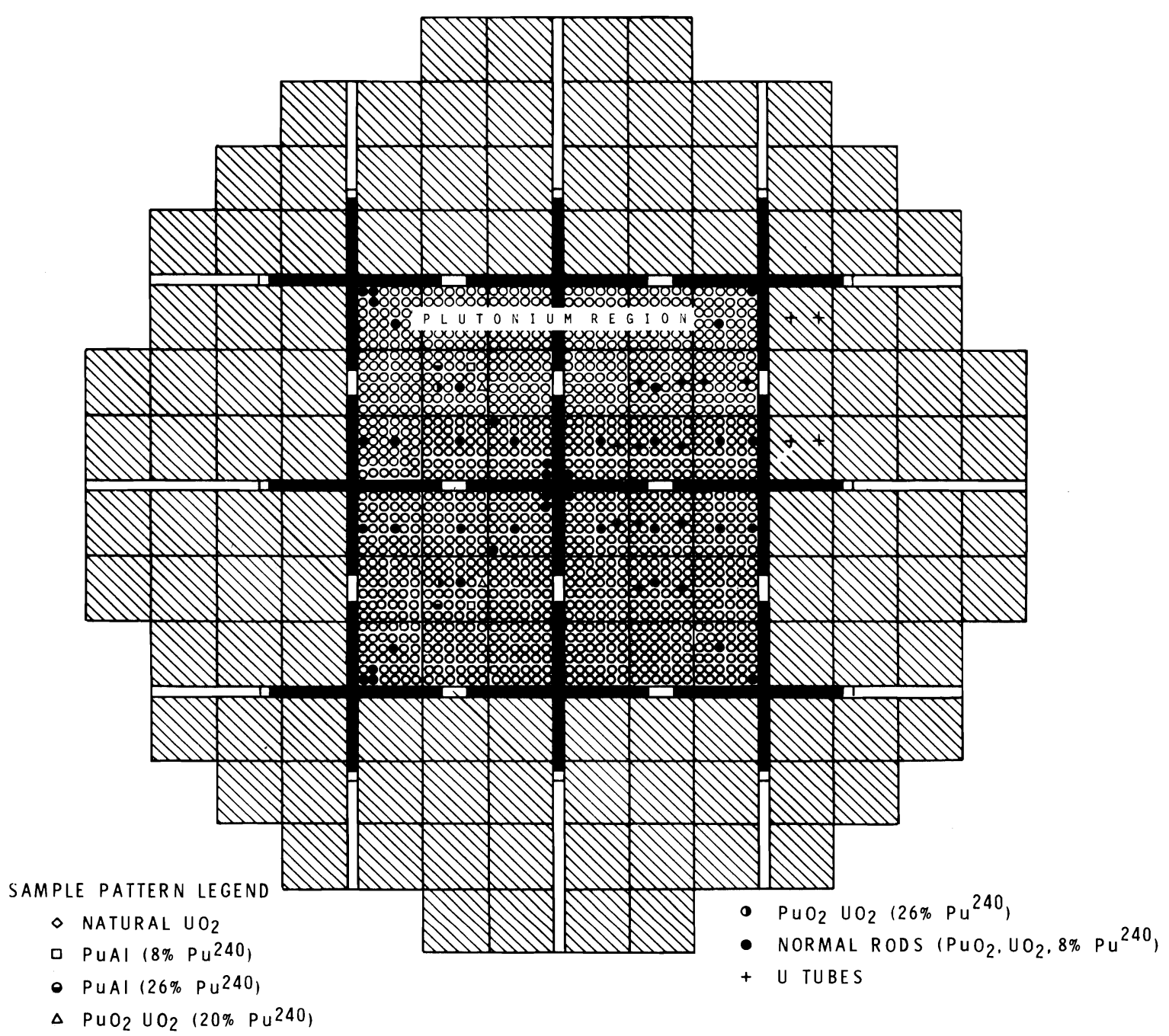

FIGURE 2. Plutonium Region of the EBWR Core 


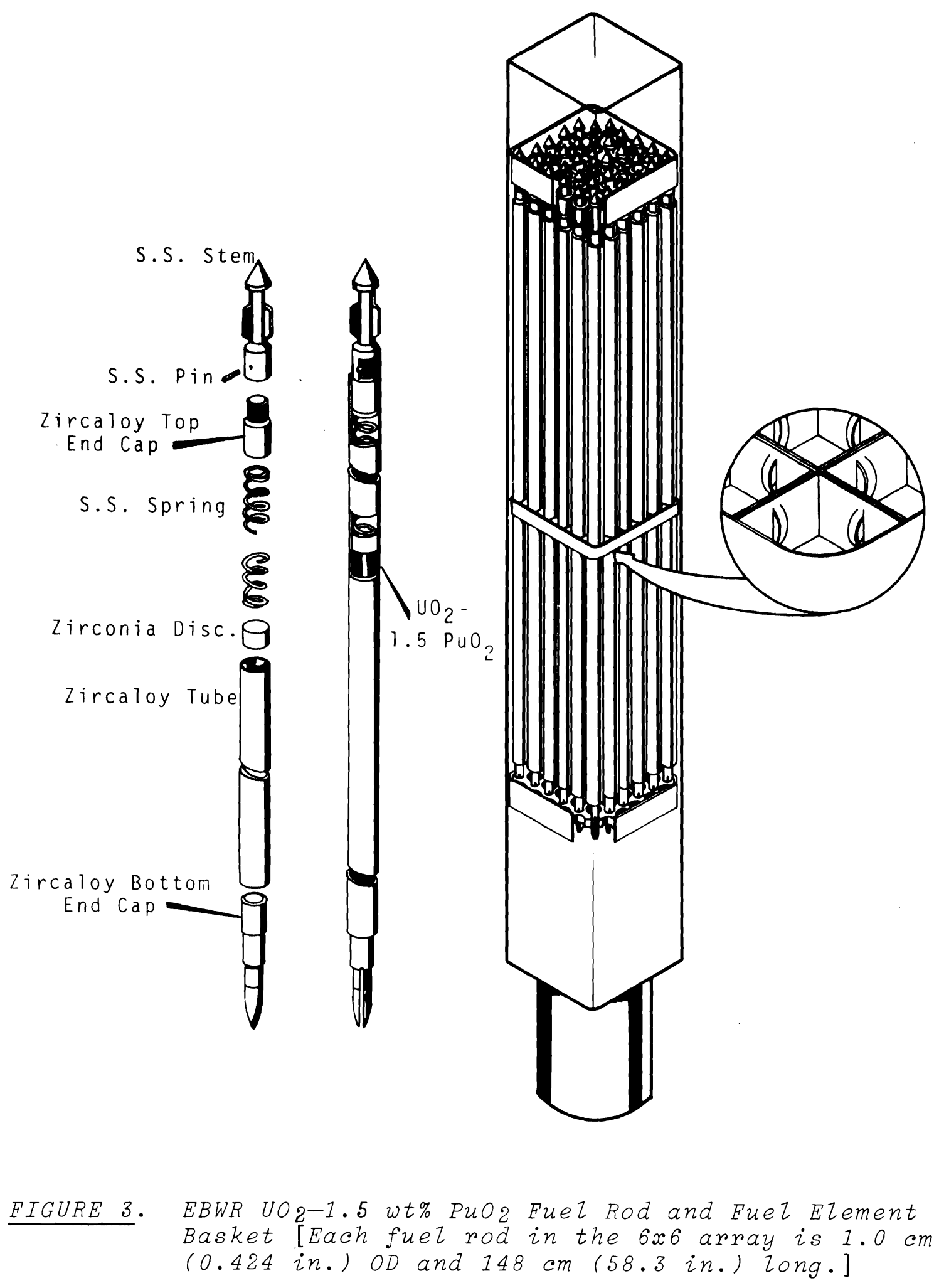


and two $\mathrm{UO}_{2}-1.5$ wt: $\mathrm{PuO}_{2}$ rods in which the atom percent of $240 \mathrm{Pu}$ was approximately $20 \%$ in one rod and approximately $26 \%$ in the other. The fuel-bearing portion of a rod is $481 / 2$ in. long and begins approximately 1 13/16 in. from the bottom of a rod.

With the core loading as described above, the EBWR reached a power level of $42 \mathrm{MW}_{t}$ on 11 November, 1966. This power level was maintained until 11 February, 1967, at which time the reactor was shut down and 17 rods were removed from the northwest quadrant (Zone 1) of the plutonium region. The average exposure achieved by the plutonium region was approximately $1300 \mathrm{MWd} /$ tonne. The positions of the 17 rods of Zone 1 and the numbers by which they are identified in this report are shown in Figure 4. The actual rod identification numbers and fuel compositions are tabulated in Table $I$. The rods were shipped from ANL to PNL during May, 1967. Gamma scanning of the rods was accomplished during June-August, 1967.

After two additional months of operation at $70 \mathrm{MW}_{t}$, the EBWR was again shut down on 29 April, 1967, and a second set of 17 rods from the southwest quadrant (Zone 2) of the plutonium region were removed. The average exposure of the plutonium fuel was approximately $2300 \mathrm{MWd} /$ tonne. These rods arrived at PNL during August, 1967. The gamma ray spectra to be shown and discussed are from this second set of rods, while the rest of the data is from the work done with the first set of rods from Zone 1 .

\section{EXPERIMENTAL PROCEDURE}

FUEL SPECTRA

Gamma ray spectra taken with the 2 in. by 2 in. NaI(T1) detector are shown in Figures 5 through 7 for a mixed oxide rod, an $\mathrm{Al}-\mathrm{Pu}$ rod, and a natural $\mathrm{UO}_{2}$ rod, respectively. 


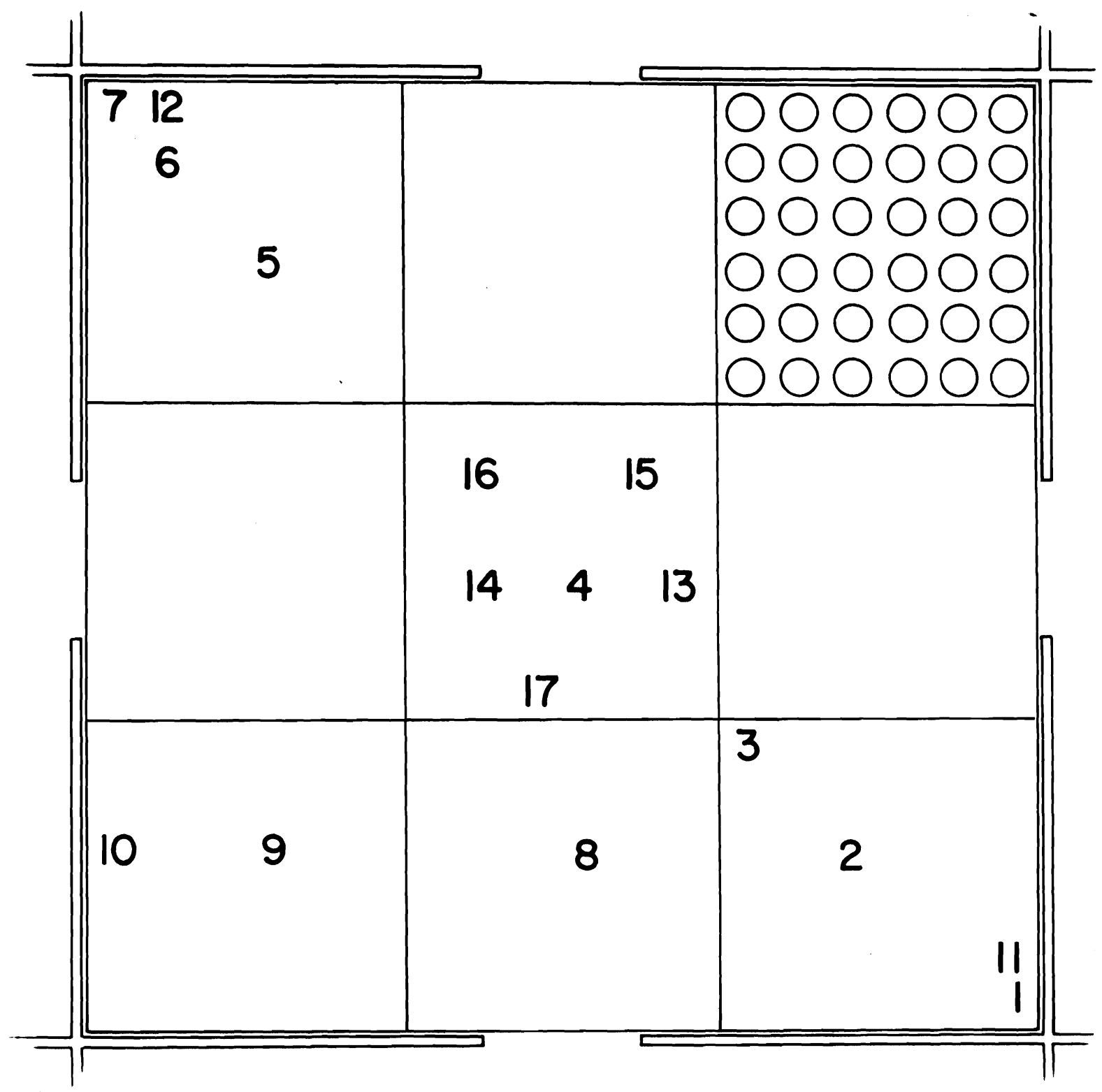

FIGURE 4. Zone 1 of EBWR Core Showing Positions of 17 Rods that Were Gamma scanned 
TABLE I. Rod Locations and Fuel Compositions

\begin{tabular}{|c|c|c|}
\hline Rod & Serial No. & Fue1 Composition \\
\hline 1 & EP98 & $\mathrm{UO}_{2}-\mathrm{PuO}_{2} \quad\left(\begin{array}{ll}8 \% & 240\end{array}\right)$ \\
\hline 2 & EL67 & $\mathrm{UO}_{2}-\mathrm{PuO}_{2}$ \\
\hline 3 & E016 & $\mathrm{UO}_{2}-\mathrm{PuO}_{2}$ \\
\hline 4 & EV71 & $\mathrm{UO}_{2}-\mathrm{PuO}_{2}$ \\
\hline 5 & EX42 & $\mathrm{UO}_{2}-\mathrm{PuO}_{2}$ \\
\hline 6 & EY 22 & $\mathrm{UO}_{2}-\mathrm{PuO}_{2}$ \\
\hline 7 & EY32 & $\mathrm{UO}_{2}-\mathrm{PuO}_{2}$ \\
\hline 8 & EI16 & $\mathrm{UO}_{2}-\mathrm{PuO}_{2}$ \\
\hline 9 & ET 54 & $\mathrm{UO}_{2}-\mathrm{PuO}_{2}$ \\
\hline 10 & EQ51 & $\mathrm{UO}_{2}-\mathrm{PuO}_{2}$ \\
\hline 11 & $\mathrm{EH} 24$ & $\mathrm{UO}_{2}-\mathrm{PuO}_{2}$ \\
\hline 12 & EX89 & $\mathrm{UO}_{2}-\mathrm{PuO}_{2} \quad\left(\begin{array}{ll}8 \% & 240\end{array}\right)$ \\
\hline 13 & EX01 & $\mathrm{UO}_{2}-\mathrm{PuO}_{2}(20 \% \quad 240)$ \\
\hline 14 & EX55 & $\mathrm{UO}_{2}-\mathrm{PuO}_{2}\left(\begin{array}{lll}26 \% & 240\end{array}\right)$ \\
\hline 15 & EU0.7 & $\left(\begin{array}{ll}8 \% & 240\end{array}\right)$ \\
\hline 16 & EU10 & $\left(\begin{array}{ll}26 \% & 240\end{array}\right)$ \\
\hline 17 & EX65 & Natural $\mathrm{UO}_{2}$ \\
\hline
\end{tabular}

Corresponding spectra taken with the GE(Li) detector are shown in Figures 8 through 10 . The spectra are for fuel rods that had cooled for approximately 115 days (Figures 5 through 7) and for 125 days (Figures 8 through 10). A tabulation of properties of the fission product nuclides contributing gamma rays to these spectra is presented in Table II.

To obtain the gamma ray spectra shown in Figures 8,9 , and 10, the sodium iodide detector was removed from the lead shield and a Ge(Li) detector, sealed in a specially constructed vacuumtight chamber, was installed. The Ge(Li) detector had a $3 \mathrm{~cm}$ by $3 \mathrm{~cm}$ surface area and a $1 \mathrm{~cm}$ depletion depth. The detector was mounted on its side so that the collimated gamma ray beam traversed a $3 \mathrm{~cm}$ path length. The measured resolution was approximately $4.0 \mathrm{keV}$ FWHM for the $662 \mathrm{keV}$ gamma ray from ${ }^{137} \mathrm{Cs}$. 


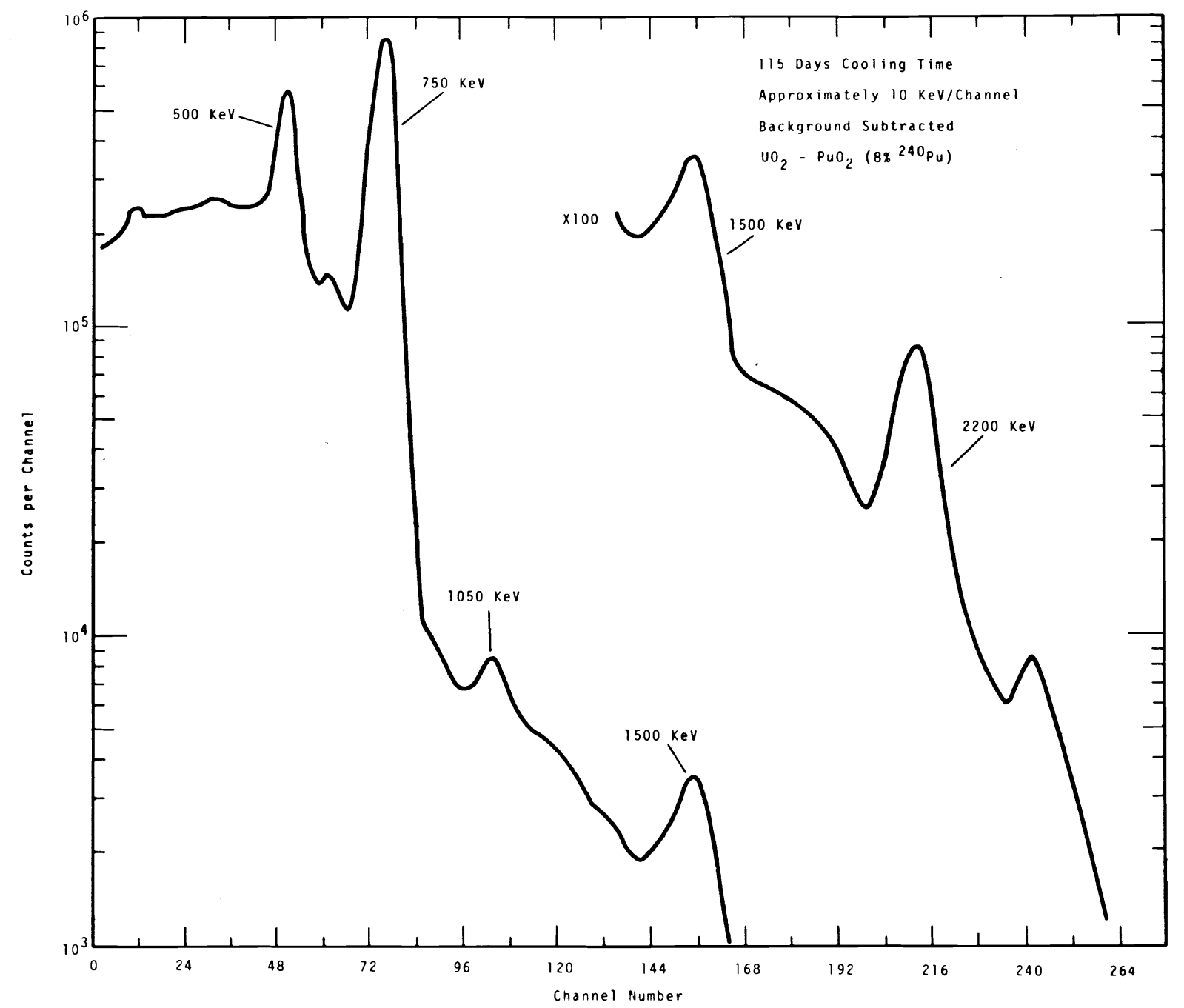

เ

罢
$\vdots$
$\vdots$
$\omega$
$\omega$

FIGURE 5. Gamma Ray Spectrum of a Mixed oxide Rod Taken with a Sodium Iodide Detector 


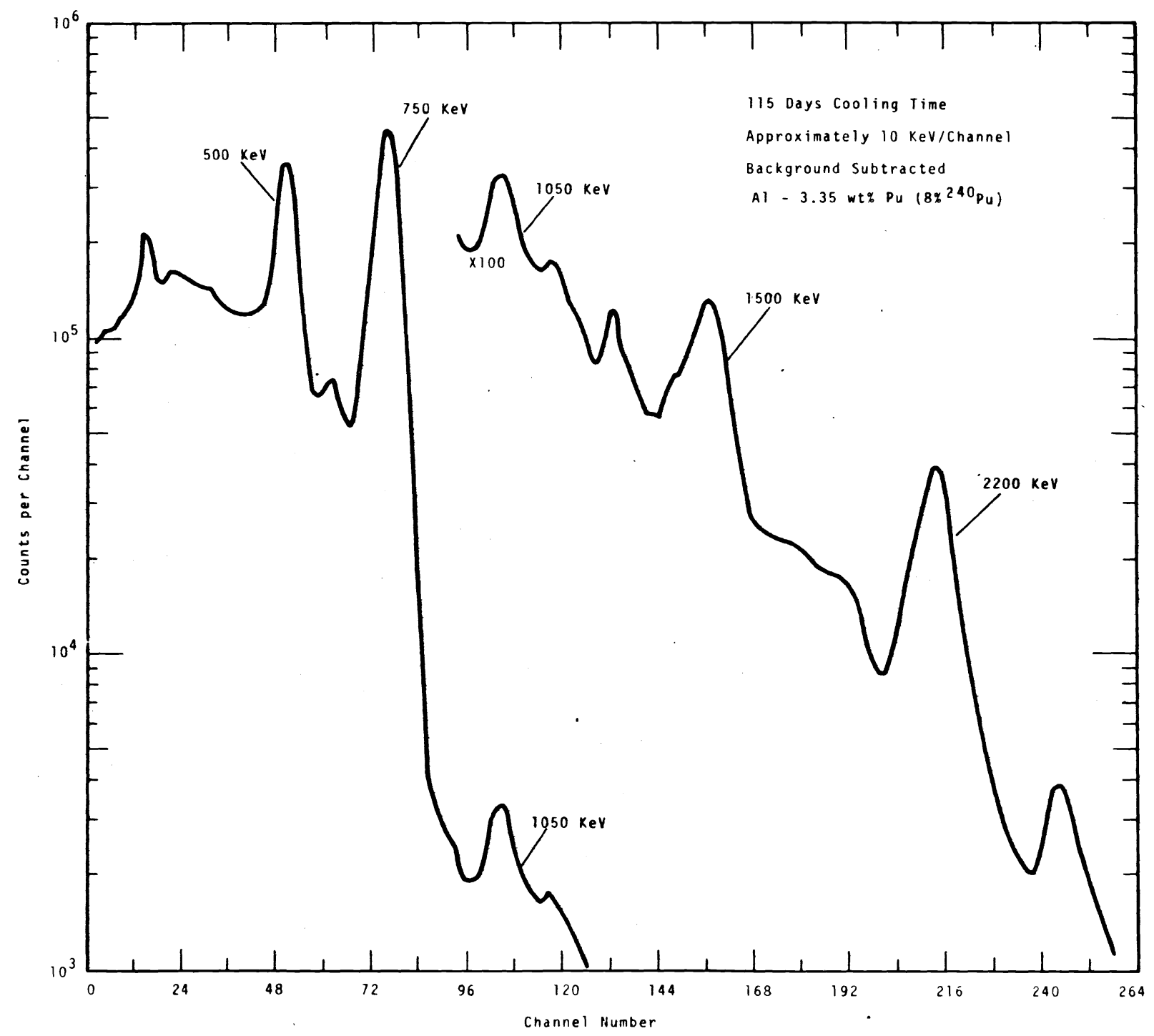




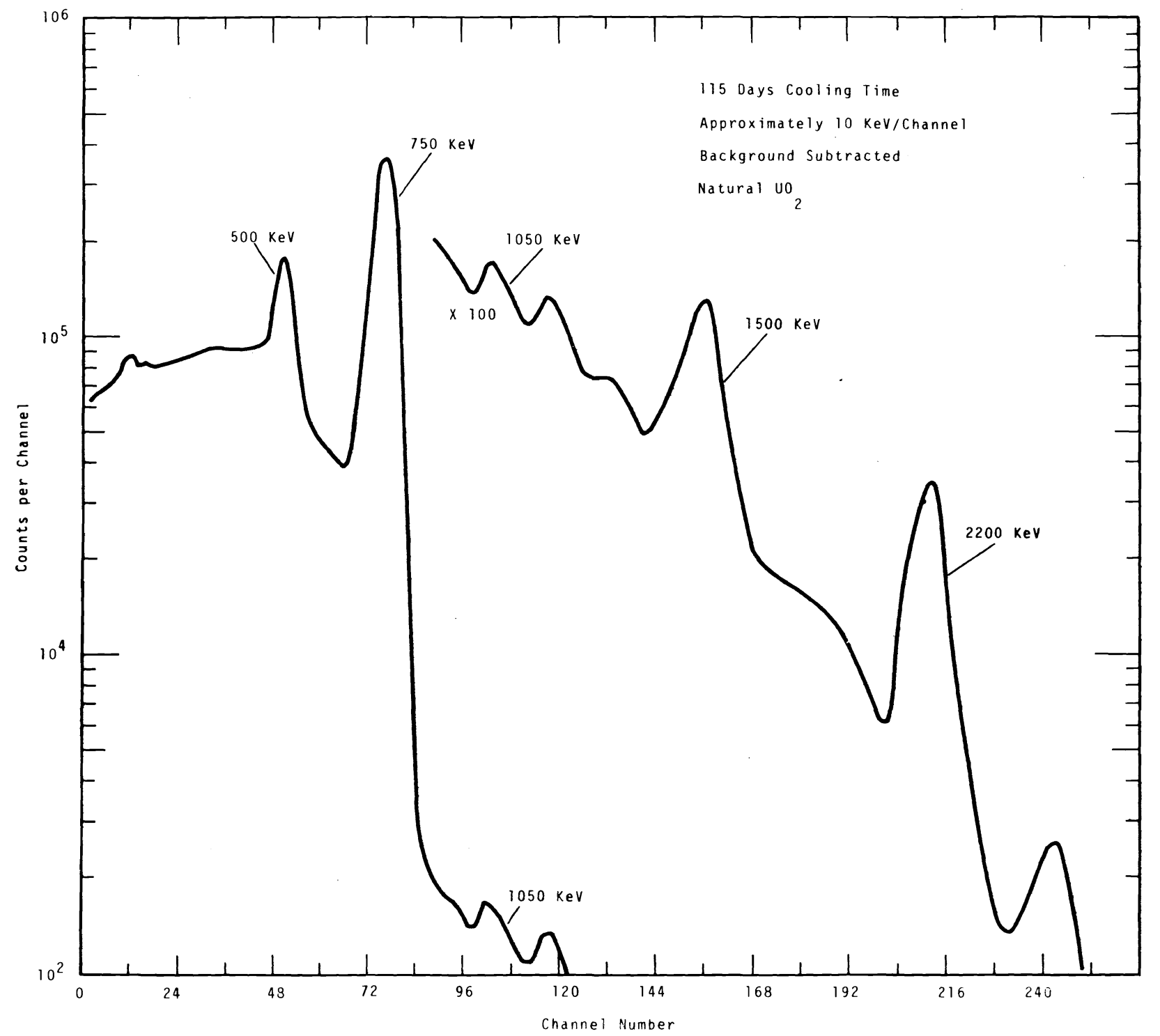

FIGURE 7. Gamma Ray Spectrum of a Natural UO ${ }_{2}$ Rod Taken with a Sodium Iodide

茎 


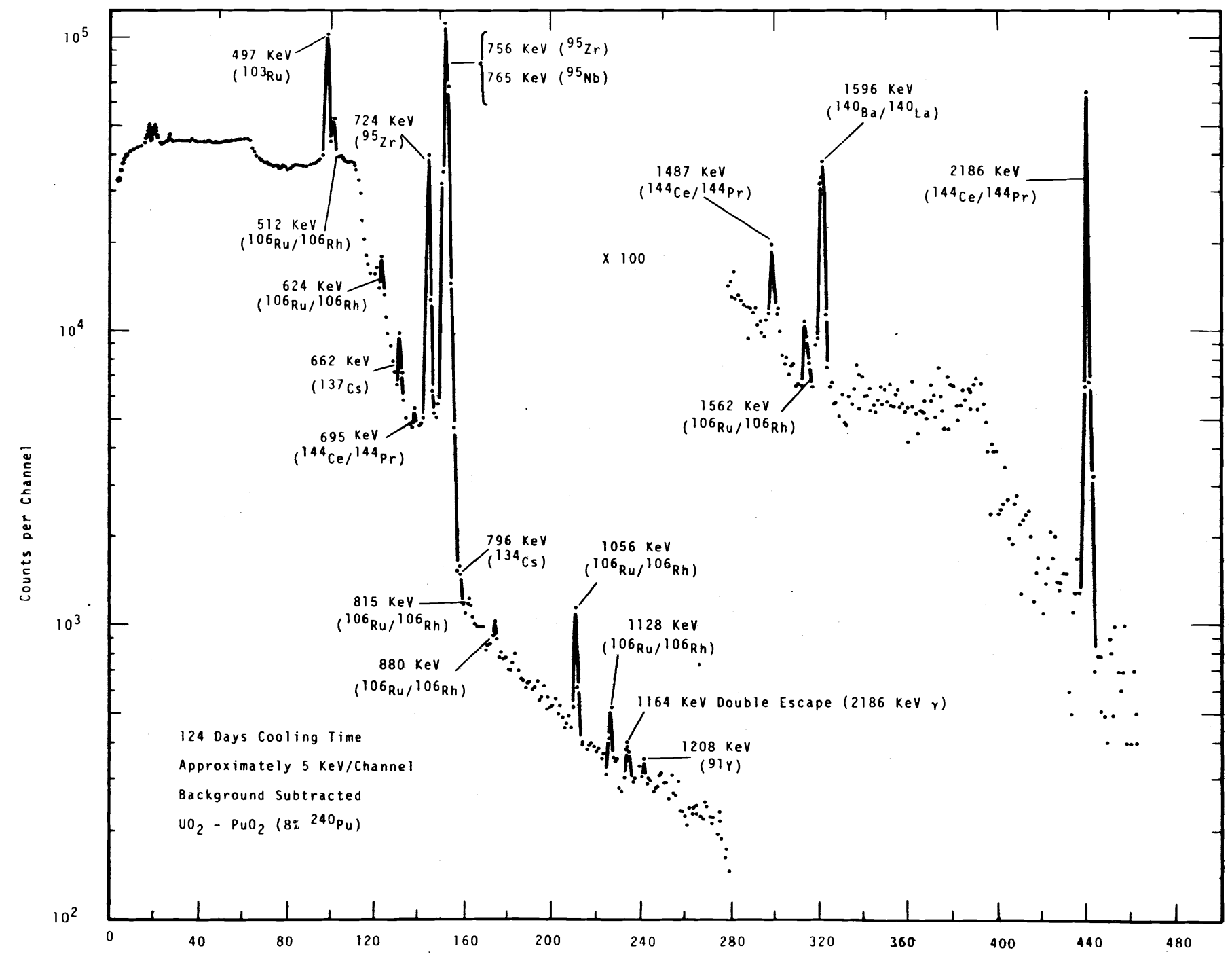




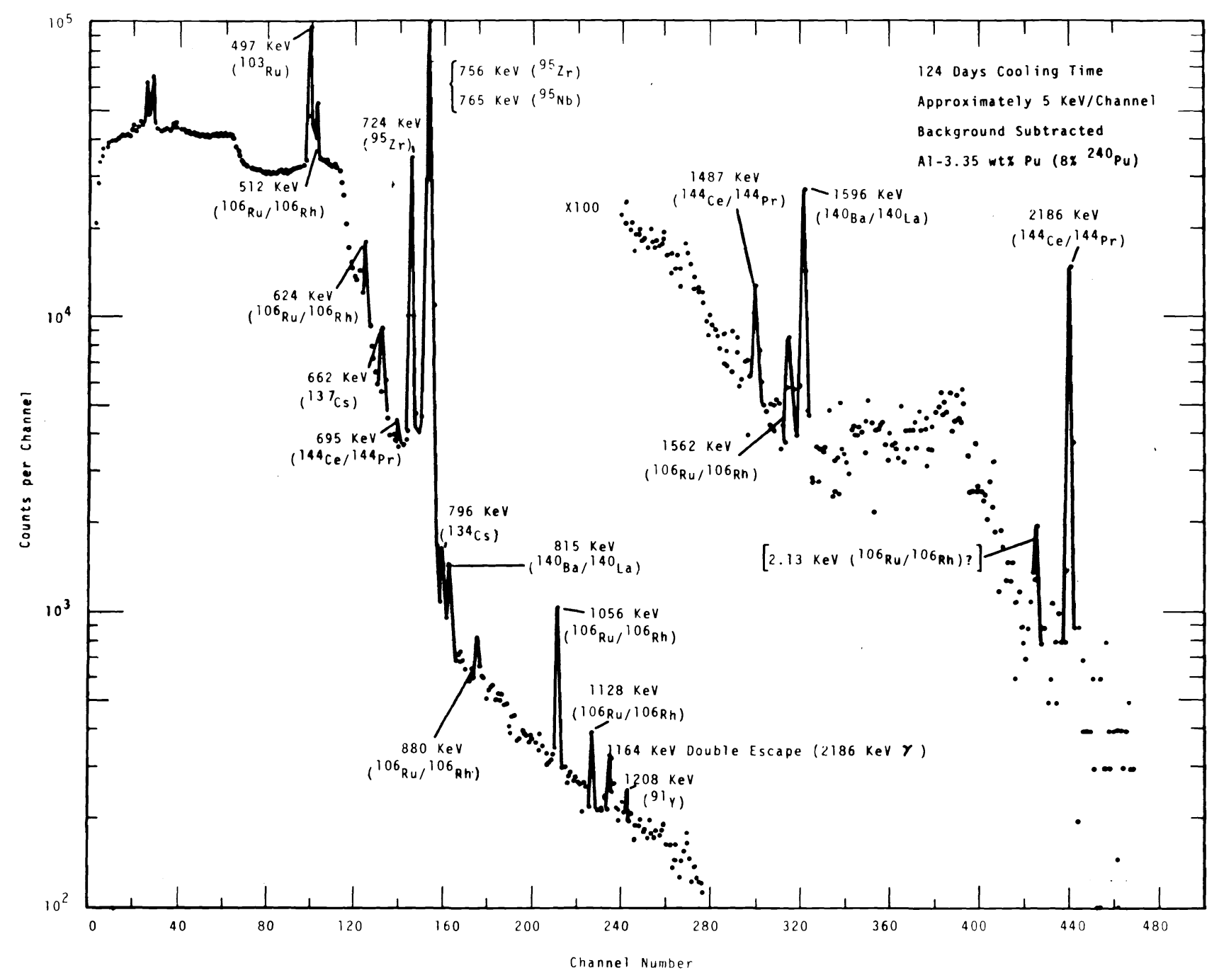

$\stackrel{+}{\circ}$

$\sum_{1}^{\infty}$
$\vdots$
$\vdots$
心
$\omega$

FIGURE 9. Gamma Ray Spectrum of an AZ-Pu Rod Taken with a Ge(Li) Detector 


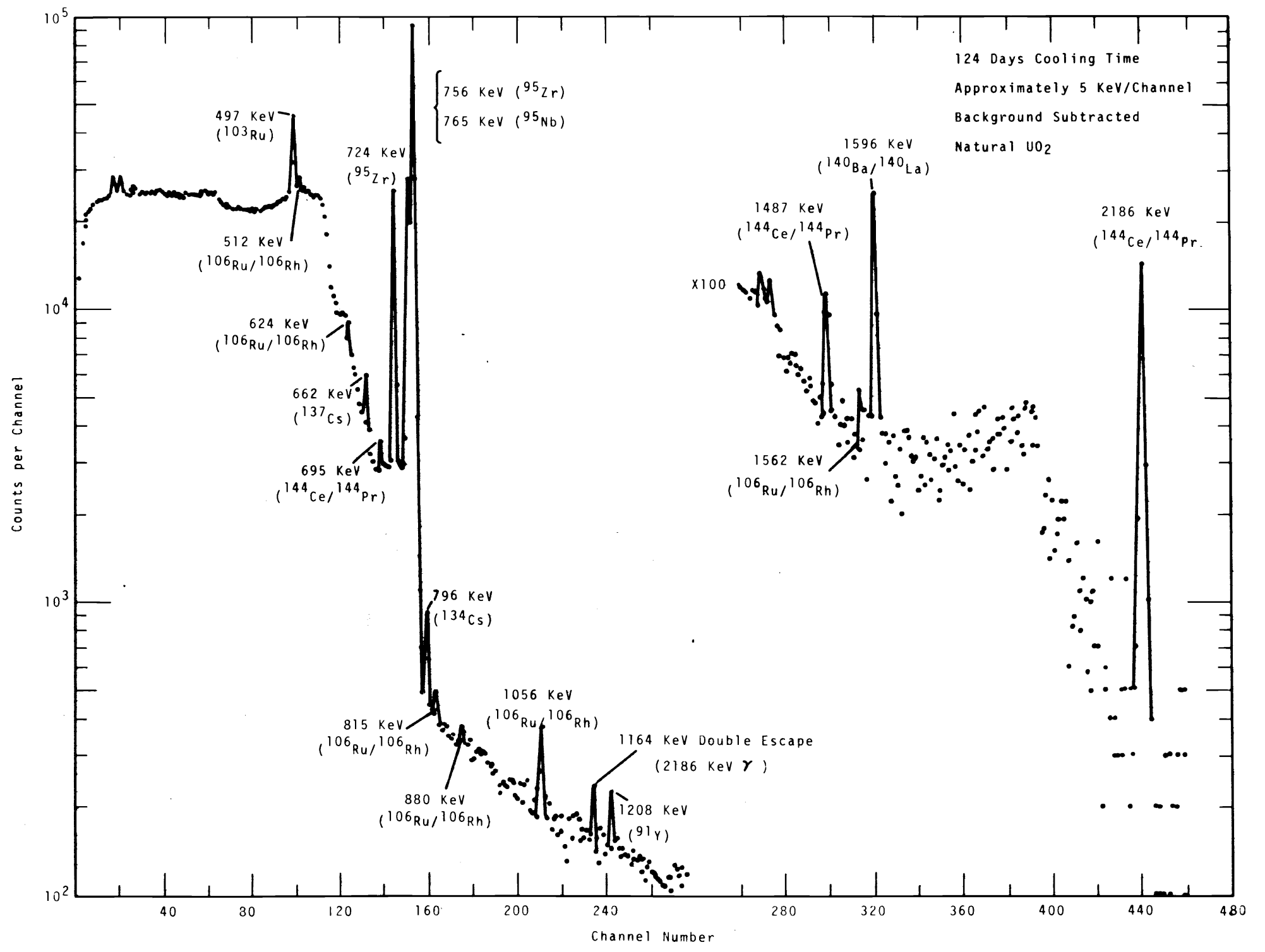

FIGURE 10. Gamma Ray Spectrum of a Natural UO 2 Rod Taken with a Ge(Li) Detector 
TABLE II. Fission Products Usejul for Gamma Scanning

$\begin{gathered}\text { Fission } \\ \text { Product }\end{gathered}$
$\frac{95_{\mathrm{Zr} /}{ }^{95} \mathrm{Nb}}{103_{\mathrm{Ru}}}$
$106_{\mathrm{Ru} /}{ }^{106_{\mathrm{Rh}}}$

$\begin{array}{ll}{ }^{134} \mathrm{Cs} & \text { From Stable }{ }^{133} \mathrm{Cs} \\ & 2.1 \mathrm{yr} \\ & 30.0 \mathrm{yr} \\ 137 \mathrm{Cs} & 12.8 \mathrm{days} / 40.2 \mathrm{hr} \\ 140 \mathrm{Ba} /{ }^{140 \mathrm{La}} & 12.8 \mathrm{days} / 40.2 \mathrm{hr} \\ & 12.8 \mathrm{days} / 40.2 \mathrm{hr} \\ & 284 \mathrm{days} / 17.3 \mathrm{~min} \\ & 284 \mathrm{days} / 17.3 \mathrm{~min} \\ & 284 \text { days } / 17.3 \mathrm{~min} \\ & 58 \mathrm{days}\end{array}$

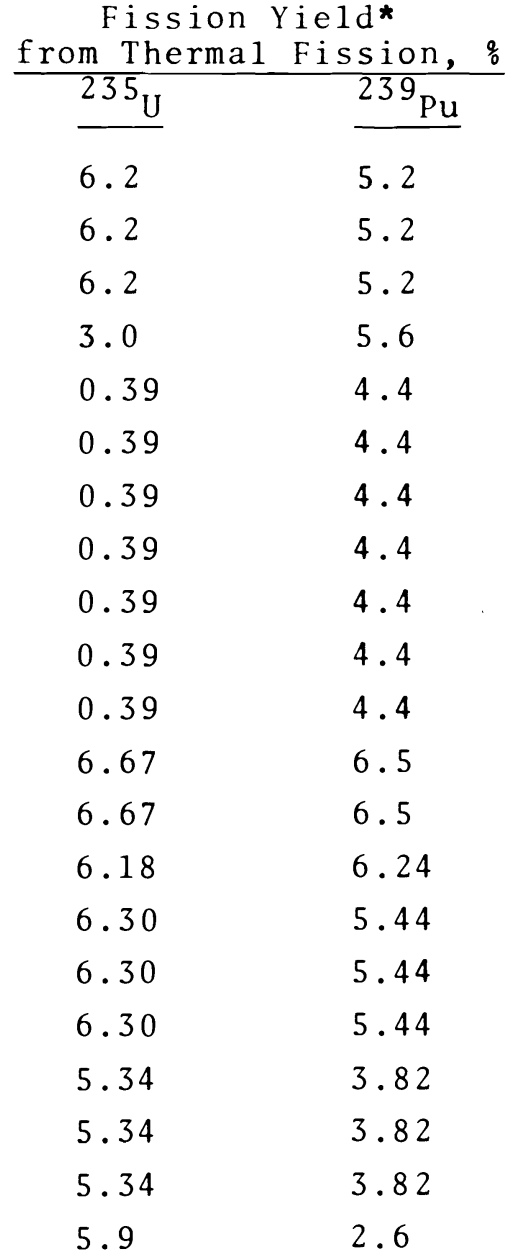

Principa 1 Gamma Rays,

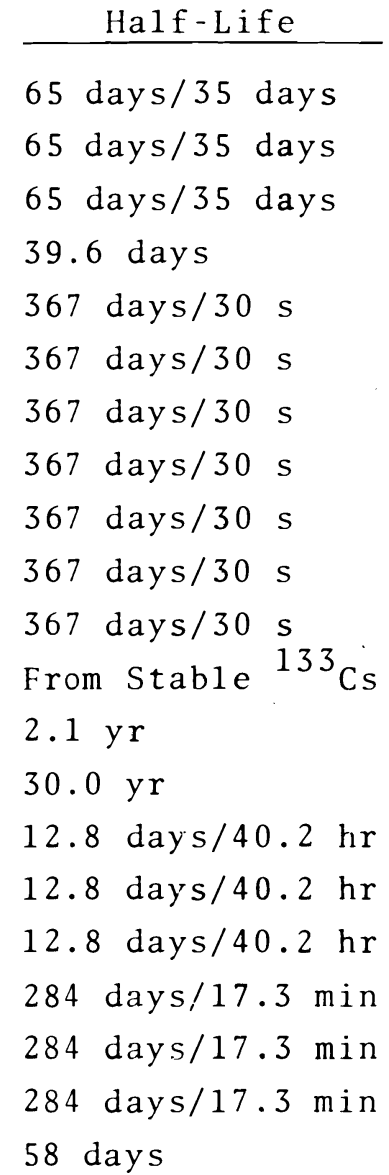

\begin{aligned} keV & \\ \hline 724 & \\ 756 & \\ 765 & \\ 497 & \\ 512 & \\ 624 & \\ 880 & \\ 1056 & \\ 1128 & \\ 1562 & \\ 2130 & \\ 605 & \\ 796 & \\ 662 & \\ 815 & \\ 1597 & \\ 2530 & \\ 695 & \\ 1487 & \\ 1208 & \\ & \\ & \\ & \\ & \\ & \\ & \\ & \\ & \\ & \\ & \\ & \end{aligned}


Two prominent intermediate energy peaks are evident in the spectra taken with the sodium iodide detector. The peak at about $500 \mathrm{keV}$ is due to a $497 \mathrm{keV}$ gamma from ${ }^{103} \mathrm{Ru}$, and a $512 \mathrm{keV}$ gamma from ${ }^{106} \mathrm{Ru} /{ }^{106} \mathrm{Rh}$. The peak at $750 \mathrm{keV}$ is due to $724 \mathrm{keV}$ and $756 \mathrm{keV}$ gammas from ${ }^{95} \mathrm{Zr}$, and to the $765 \mathrm{keV}$ gamma from ${ }^{95} \mathrm{Nb}$. The intensity of the $500 \mathrm{keV}$ peak relative to that of the $750 \mathrm{keV}$ peak is smallest for the natural $\mathrm{UO}_{2}$ rod and largest for the $\mathrm{Al}-\mathrm{Pu}$ rod because of the higher thermal fission yields of ${ }^{103} \mathrm{Ru}$ and ${ }^{106} \mathrm{Ru}$ from ${ }^{239} \mathrm{Pu}$ fission than from ${ }^{235_{\mathrm{U}}}$ fissions (see Table II).

In addition to the two prominent gamma peaks in the spectra taken with the sodium iodide detector, lower intensity peaks are at approximately $1050 \mathrm{keV}, 1500 \mathrm{keV}$, and $2200 \mathrm{keV}$. The peak at $1050 \mathrm{keV}$ is due mainly to the $1056 \mathrm{keV}$ gamma from ${ }^{106} \mathrm{Ru} /{ }^{106} \mathrm{Rh}$. The peak is also much stronger in the gamma spectra of the plutonium fuel rods than in the spectrum of the natural $\mathrm{UO}_{2}$ rod. The peak at $1500 \mathrm{keV}$ is due mainly to the $1487 \mathrm{keV}$ gamma ray from ${ }^{144} \mathrm{Ce} /{ }^{144} \mathrm{Pr}$ and the $1596 \mathrm{keV}$ gamma ray from ${ }^{140} \mathrm{Ba} /{ }^{140} \mathrm{La}$. The peak at $2200 \mathrm{keV}$ is due mainly to the $2186 \mathrm{keV}$ gamma from ${ }^{144} \mathrm{Ce} /{ }^{144} \mathrm{Pr}$.

A significant gamma ray, not clearly resolved in spectra taken with the sodium iodide detector but evident in spectra taken with the Ge(Li) detector, is the $1208 \mathrm{keV}$ gamma ray from ${ }^{91} Y$. This gamma is more prominent in the natural $\mathrm{UO}_{2}$ rod spectrum than in spectra of fuel rods containing significant amounts of plutonium. The ${ }^{91} \mathrm{Y}$ has a higher thermal fission yield for $235 \mathrm{U}$ than for ${ }^{239} \mathrm{Pu}$.

SCANN ING

For scanning the fuel rods, the single channel analyzer bias was set at $675 \mathrm{keV}$ and all pulses above this energy were counted. Thus, in effect, the ${ }^{95} \mathrm{Zr} /{ }^{95} \mathrm{Nb}$ peak at $750 \mathrm{keV}$ was 
used for scanning. To determine whether the energy interval would affect the result of a rod scanning experiment, two rods were scanned by the normal procedure and also by counting pulses under the $500 \mathrm{keV}$ photopeak. For the $500 \mathrm{keV}$ photopeak scans, the single channel analyzer was biased to accept pulses in the energy interval of $420 \mathrm{keV}$ to $620 \mathrm{keV}$. Ratios were formed of counts above $675 \mathrm{keV}$ to counts under the $500 \mathrm{keV}$ photopeak for each rod point at which data was obtained. The results are shown in Figures 11 and 12 . The value of the ratio at any point does not deviate from the average value of the ratio by more than the uncertainty in the data. It thus appears that for these EBWR rods, results obtained for a rod scan using the $500 \mathrm{keV}$ photopeak are the same as for the ${ }^{95} \mathrm{Zr} /{ }^{95} \mathrm{Nb} 750 \mathrm{keV}$ photopeak. Because the neutron spectrum in the EBWR is predominantly thermal and temperature of the fuel rods during irradiation is not high enough to cause appreciable fission product migration, scanning results independent of the fission product chosen for observation are expected, provided that the fission product does not saturate during fuel rod irradiation. For these EBWR rods, residence time in the reactor (90 days), and cooling time prior to counting (115 to 150 days), are such that both ${ }^{95} \mathrm{Zr} /{ }^{95} \mathrm{Nb}$ and ${ }^{106} \mathrm{Ru} /{ }^{106} \mathrm{Rh}$ are useful fission monitors.

A rod in the present gamma scan facility cannot be rotated while being scanned. Each rod, therefore, was oriented with reference to the detector to give the maximum counting rate at a position determined to be 10 in. from the bottom of the fuel. Variations of 2 to $5 \%$ in count rate were noted when rods from the outer rows in an element were rotated $360^{\circ}$. Small variations ranging from $<2 \%$ to no significant change of count rate were observed with rotation of rods from inner rows of a fuel element.

To correct for drifts in electronics resulting from deterioration of components and fluctuations in temperature, 


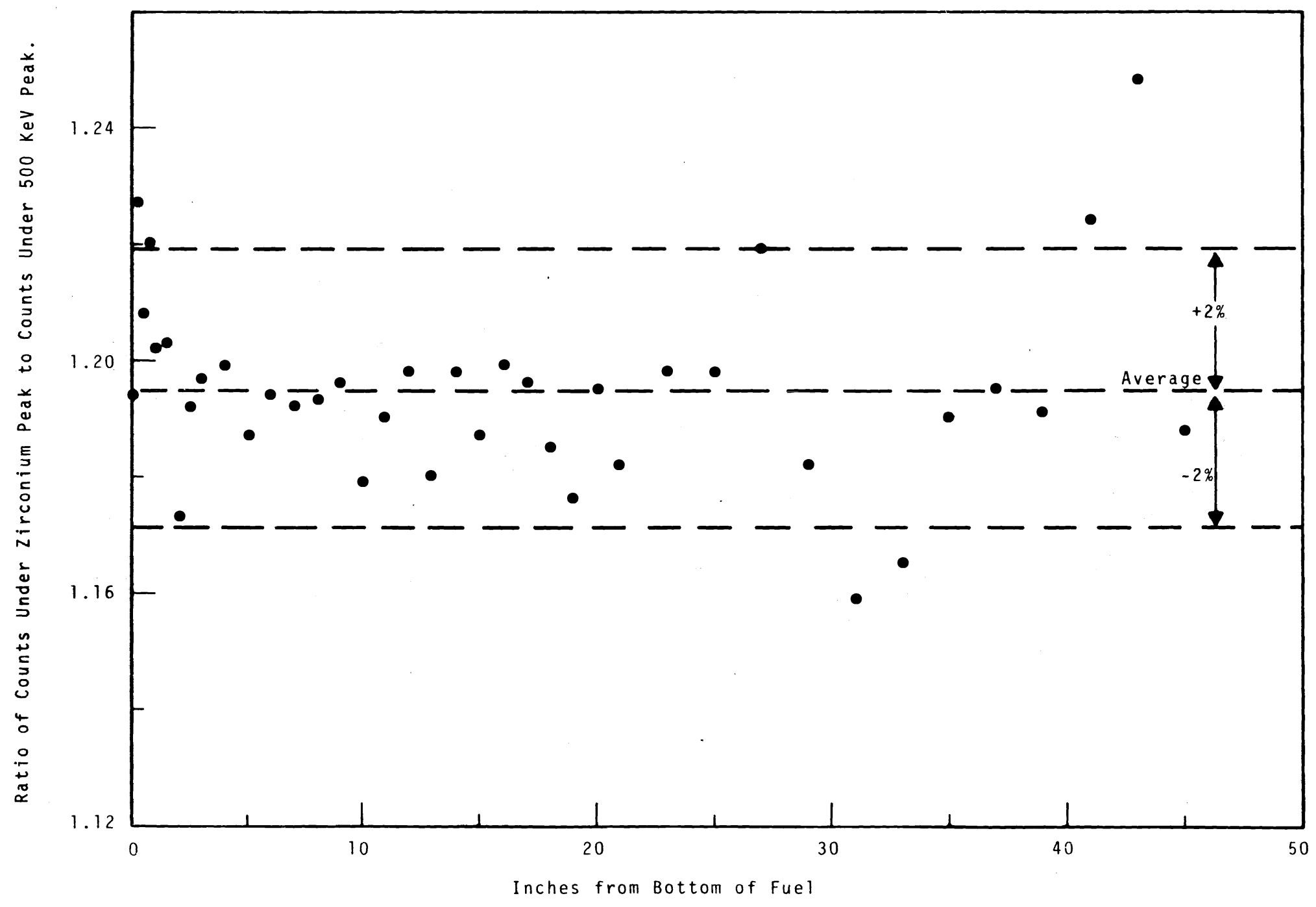




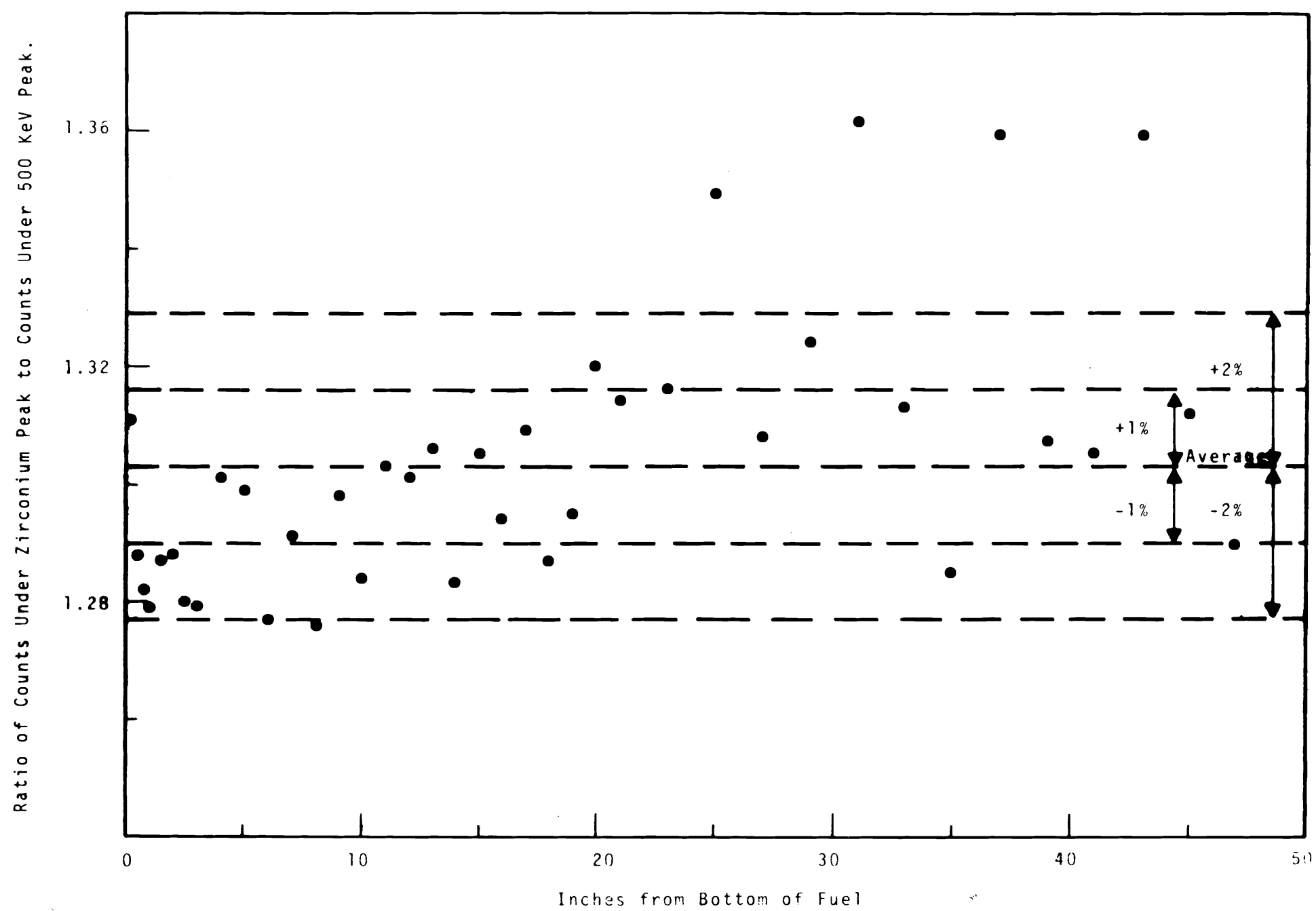

FIGURE 12. Comparison of Gamma Scan Data for Rod Number 15 Using Two Different Energy Intervals 
the counting equipment was calibrated at frequent intervals with a ${ }^{137} \mathrm{Cs}$ source. The calibration procedure consisted of adjusting the linear amplifier gain with the single channel analyzer bias set at the leading edge of the $662 \mathrm{keV}$ photopeak, to obtain a specified count rate. Due to large and frequent changes in temperature at the PRTR fuel storage basin, it was necessary to compensate for electronic drift every 10 to 15 minutes. Compensation for electronic drift permitted reproduction of rod count rates to within their standard deviations. DATA ANALYSIS

Gross count rates were corrected for background ( 1000 counts/min) and for the contribution due to zirconium in the fuel rod cladding. Background was found to be due almost entirely to other fuel rods stored in the basin. No change in background was observed when a rod was removed from its normal scanning position on the fuel tray.

The correction for zirconium in the cladding was determined by making a count at a point $1 / 4$ in. below the bottom of the fuel. At this point, the observed count was due entirely to radioactive zirconium. This count was then multiplied by factors to correct for the volume of the cladding and for the change in thermal neutron flux with position along the rod. The zirconium cladding correction was 1 to $2 \%$ of the gross count rate.

Six weeks elapsed between the scan of the first rod and the scan of the last rod. At the conclusion of the individual rod scans, al1 17 rods were scanned at 6 selected points. This procedure was used to normalize the scans so that relative burnup between rods at different positions in the reactor could be determined. By repeating the experiment on one of the rods, the reliability of the normalization procedure was determined to be $\pm 1 \%$. 
Data at individual points along a rod were found experimentally to be reproducible to within $\pm 1 \%$ except near the top of the fuel where low count rates gave rise to larger standard deviations. In addition to the standard deviation, another factor limiting reproducibility of the data was the short term random fluctuations in count rate attributed to random gain shifts in the linear amplifier. The accuracy of positioning the scanner head on a fuel rod was $\pm 1 / 32$ in., and the accuracy with which the end of the fuel could be determined was $\pm 1 / 16$ in. Together, these positioning uncertainties introduce $\pm 1 \%$ in the uncertainty of the data. Taking into account the uncertainties associated with individual count reproducibility, the positioning of the scanner head, and the normalization procedure, the overall uncertainty in the data for this experiment is believed to be $\pm 3 \%$.

\section{RESULTS AND DISCUSSION}

A gamma scan of a typical fuel rod is shown in Figure 13. The peak in gamma activity occurs approximately 11 in. from the bottom of the fuel. There is very little burnup in the top 15 in. of fuel. This asymmetrical burnup pattern results from an increase in concentration of moderator voids near the top of the EBWR core and also from the fact that the EBWR control rods were active at the top of the core. A slight flux peaking is evident in the bottom inch of the fuel.

Gamma scans of seven mixed oxide rods, radially positioned, (see Figure 4 and Table I) are presented in Figure 14. Rod No. 1 at the center of the core has the highest burnup. The burnup of Rod No. 1 appears to be about twice as much as that of a typical rod in the center of a fuel element. The finding that rods at the edges of the fuel elements achieve greater burnup than do those at interior positions would indicate that the fuel rods near the middle of an element are undermoderated. The 


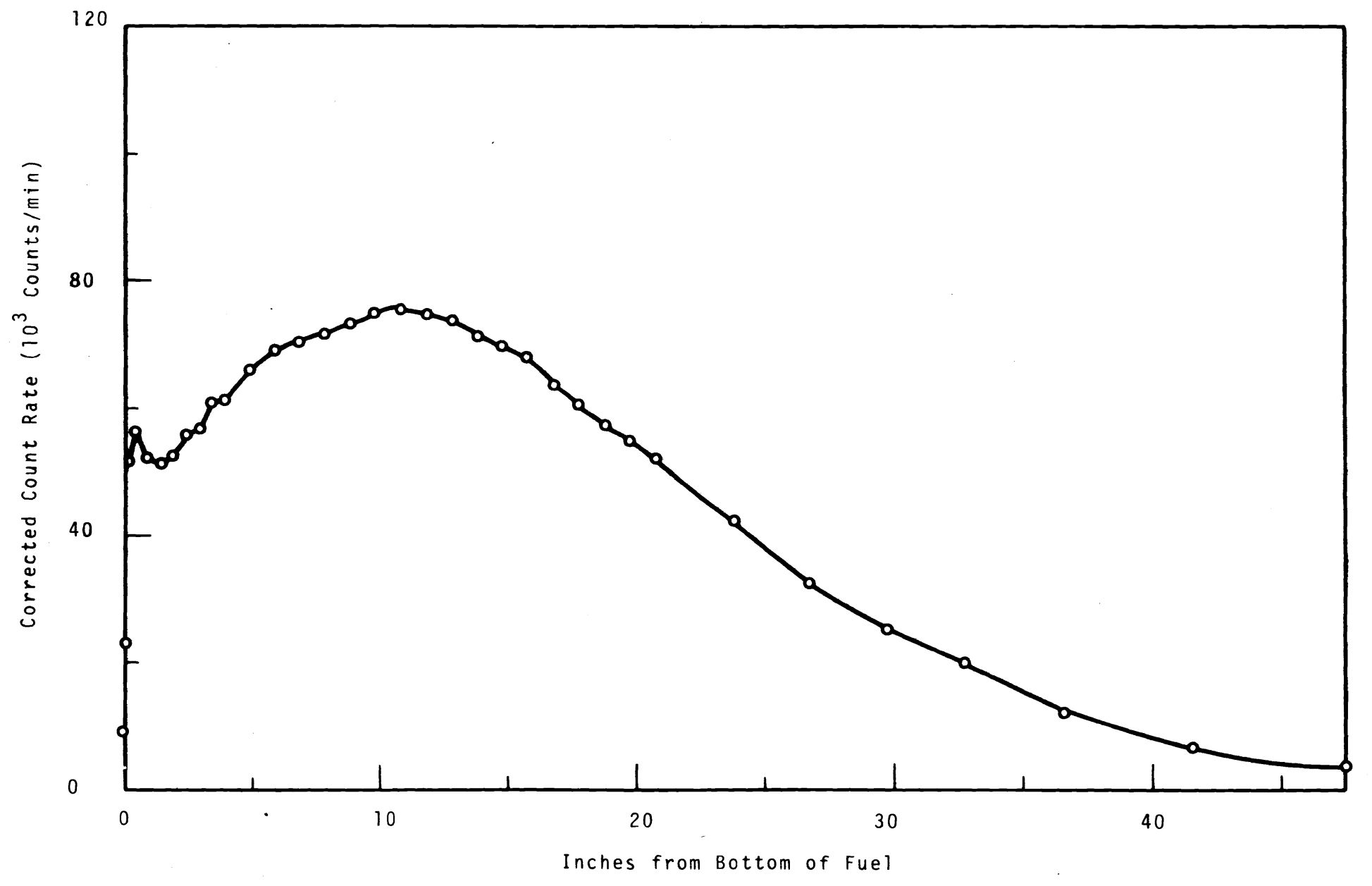




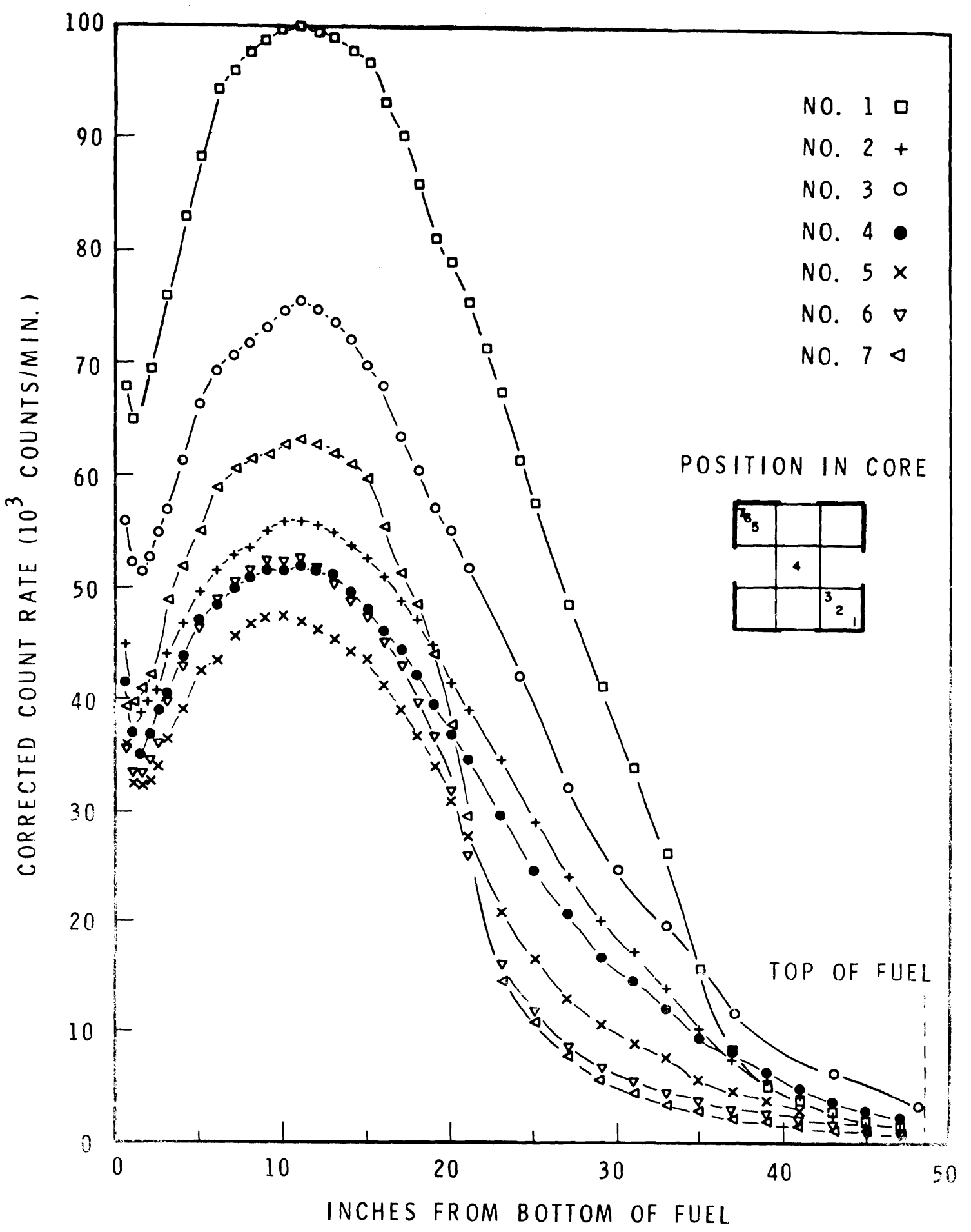

FIGURE 14. Gamma Scans of Radial Rods 
burnup profile in the radial direction at a point 10 in. from the bottom of the fuel is shown for the seven radially positioned mixed oxide rods in Figure 15 .

Probably the major factor influencing the burnup profile of the EBWR rods is the void concentration in the water moderator. That the control rods also affect the burnup profile is evident from Figure 14. For clarity, gamma scans of rods 1, 5, 6 , and 7 are shown separately in Figure 16. It is evident from Figure 16 that the active portion of the center control rod ends about 35 in. above the bottom of the fuel, while the active portion of the control rod adjacent to fuel rod 7 ends about 23 in. above the bottom of the fuel. The effect of the control rod in depressing the burnup at the top of a fuel rod can be clearly seen by comparing the gamma scans of rods 5,6 , and 7 . The control rod adjacent to rod 10 was also active at about 23 in. above the bottom of the fuel, as shown in Figure 17, and it is noted that rods 1 and 11 indicate the same position of the center control rod. Rods 7 and 12 indicate the same location of the active portion of the control rod next to these two rods.

Gamma scans for rods 2, 8, 9, and 10 are shown in Figure 18. These scans confirm the preceding general observations.

Gamma scans of the special rods in the center fuel element are shown in Figure 19. For purposes of comparison, the scan of the mixed oxide rod 4 is also shown. Because of differences in fuel weight and fuel composition among the several special rods, the data have been normalized to unity at the highest count on each rod. Figure 18 shows that differences in fuel composition do not effect the burnup pattern achieved by the rods in this core.

The area beneath each curve was integrated to determine average and peak-to-average values for the rods. These values are tabulated in Table III. 


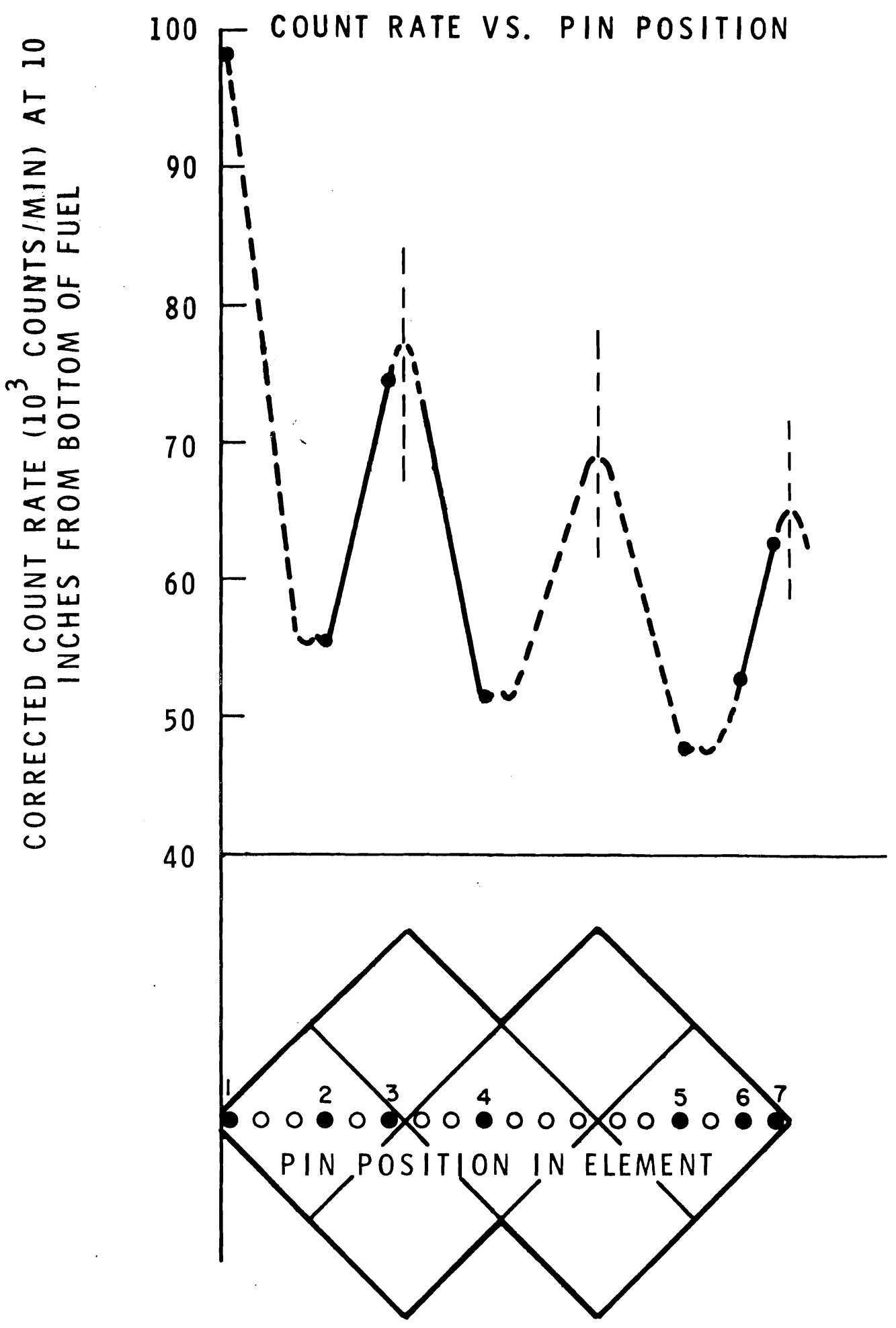

FIGURE 15. Radial Burnup Profile $10 \mathrm{in.}$ from Bottom of Fuel 


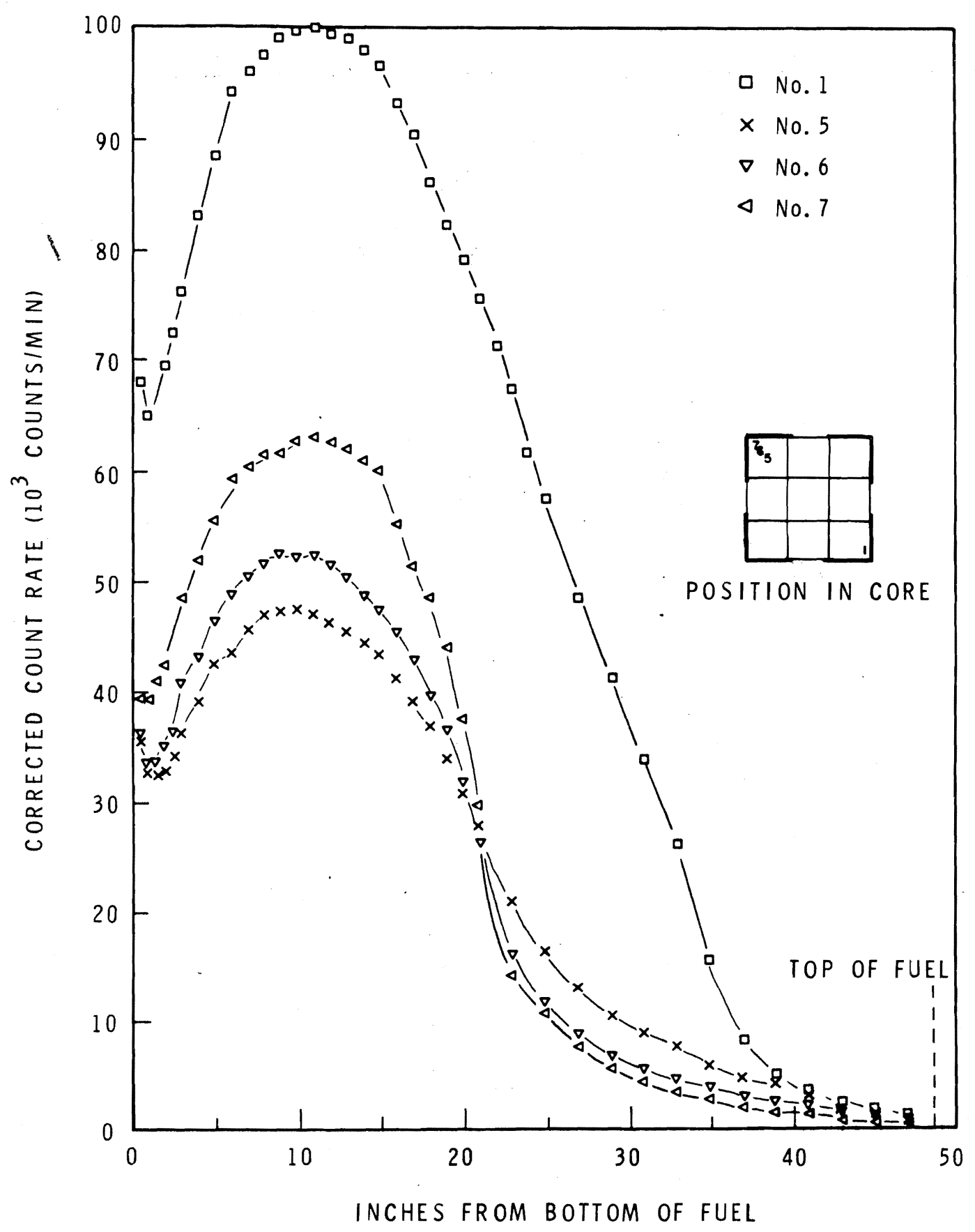

EIGURE 16. Gamma scans of Fuel Rods Numbers 1, 5, 6, and? 


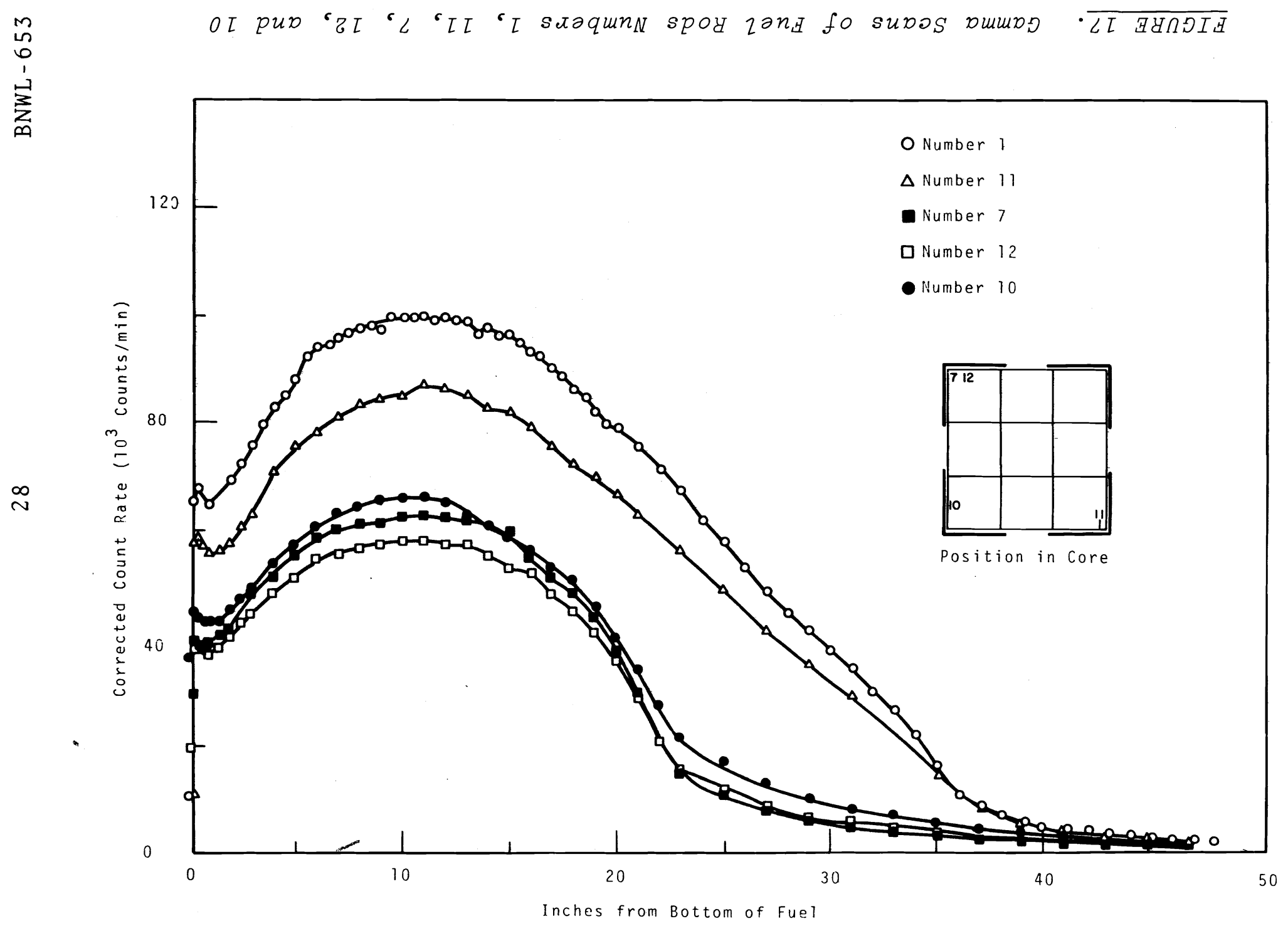




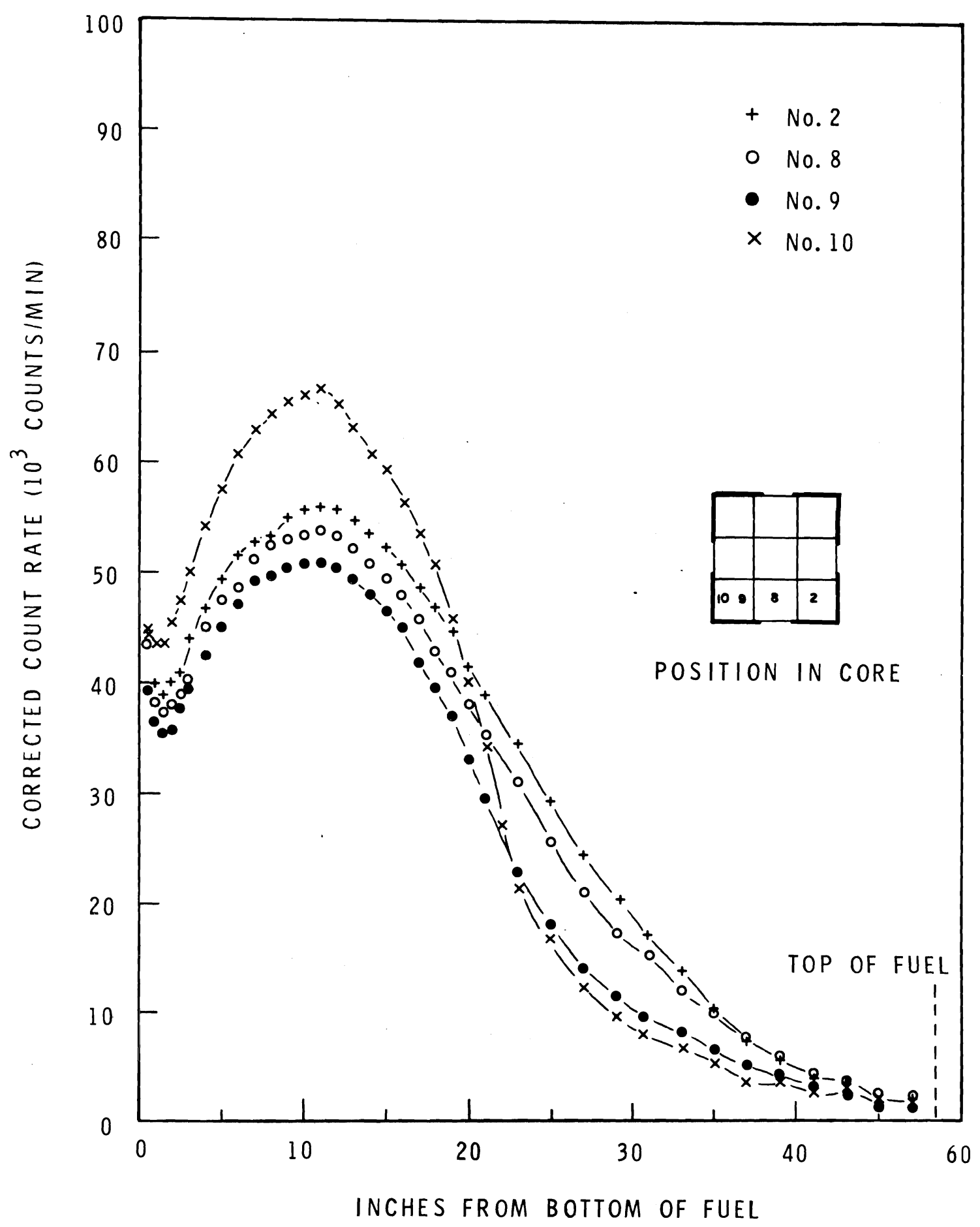

FIGURE 18. Gamma Scans of Fods Numbers 2, 8, 9, and 10 


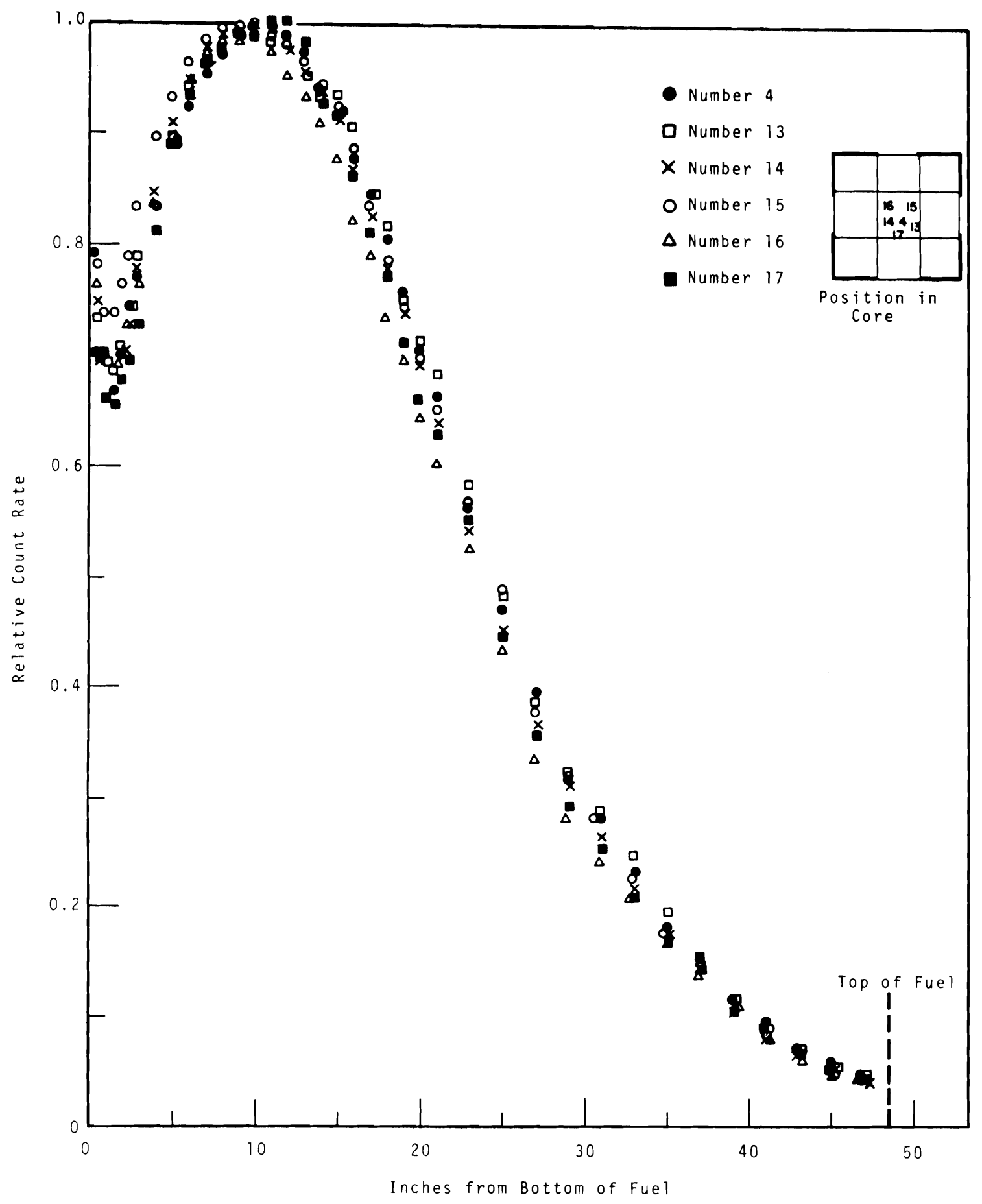

FIGURE 19. Gamma Scans of Special Rods 
TABLE III. Peak-to-Average Values

\begin{tabular}{|c|c|c|c|c|}
\hline Rod & Identification & Peak & Average & Peak/Average \\
\hline 1 & EP98 & 100,110 & 53,170 & 1.883 \\
\hline 2 & EL67 & 55,950 & 30,000 & 1.865 \\
\hline 3 & E016 & 75,520 & 39,630 & 1.906 \\
\hline 4 & EV71 & 51,980 & 27,500 & 1.890 \\
\hline 5 & EX42 & 47,290 & 22,890 & 2.066 \\
\hline 6 & EY22 & 52,390 & 23,180 & 2.260 \\
\hline 7 & EY32 & 63,070 & 26,860 & 2.348 \\
\hline 8 & EI 16 & 53,430 & 28,230 & 1.892 \\
\hline 9 & ET 54 & 50,990 & 24,810 & 2.055 \\
\hline 10 & EQ51 & 66,430 & 29,560 & 2.247 \\
\hline 11 & EH 24 & 81,000 & 46,280 & 1.880 \\
\hline 12 & EX89 9 & 58,380 & 25,450 & 2.294 \\
\hline 13 & EX01 & 59,170 & 31,430 & 1.882 \\
\hline 14 & EX 55 & 47,580 & 24,670 & 1.929 \\
\hline 15 & EU07 & 47,280 & 25,210 & 1.876 \\
\hline 16 & EU1 0 & 40,500 & 20,400 & 1.985 \\
\hline 1.7 & EX65 & 30,420 & 15,490 & 1.964 \\
\hline
\end{tabular}

\section{FURTHER ANALYSIS}

The results presented here have been used, first, to select rods and sample locations for destructive analysis of the fuel. Later, the results of the destructive analyses will be correlated with these results. Also, calculations are being done by CNEN and PNL for comparison with these results.

\section{ACKNOWLEDGMENTS}

We appreciate and hereby acknowledge the work of Orrand Fiskum and Ivan Kirkelie in fuel rod movements in the basin of the PRTR, the help of Arne Penttila in taking measurements, and the work of Elizabeth Reppond in processing the data. 


\section{REFERENCES}

1. R. C. Liikala, U. P. Jenquin, and W. A. Reardon. The PuO2-UO2 Experiment in the EBWR. BNWL-126, Pacific Northwest Laboratory, Richland, Washington, June 1965.

2. B. J. Toppel, P. J. Vogelberger, Jr., and E. A. Wimunc. Safety Analysis Associated with the Plutonium Recycle Experiment in EBWR, ANL-6841, Argonne National Laboratory, November 1966 .

3. P. Kristiansen and T. Rogeberg. "Non-Destructive Analysis of Irradiated Fuel Elements," Final Report, Research Contract No. 47 between IAEA and IFA, Kjeller, Norway 1962.

4. W. R. Diggle and W. H. Blackadder. "Gamma Scanning for Burnup," Nucleonics, vol. 23, p. 71, March 1965.

5. M. F. Banham, A. J. Fudge, and J.H. Howes. The Use of Lithium Drifted Germanium Diodes for the Gamma Spectrometric Determination of Radioactive Fission Product Nuclides, AERE-M-1606. Gr. Brit. Atomic Energy Research Establishment, Harwell, Burks, England, June, 1965.

6. R. S. Forsythe and N. Ronquist. Burn-up Determination by High Resolution Gamma Spectrometry: Spectra from SlightlyIrradiated Uranium and Plutonium Between $400-830 \mathrm{keV}$, AE-241. Aktiebolaget Atomenergi, Stockholm, Sweden, 1966 .

7. R. S. Forsytn, W. H. Blackadder, and N. Ronquist. Burn-up Determination by High Resolution Gamma Spectrometry: Axial and Diametral Scanning Experiments, AE-267. Aktiebolaget Atomenergi, Stockholm, Sweden, 1967 .

8. J. A. Sovka. Nondestructive Analyses of Irradiated MITR Fuel by Gamma Ray Spectroscopy. Massachusetts Institute of Technology, September, 1965. (Ph.D. Thesis)

9. R. E. Sharp and W. J. Bailey. Design, Fabrication and Irradiation of $\mathrm{UO}_{2}-\mathrm{PuO}_{2}$ Fuel Rods for the Experimental Boiling Water Reactor, BNWL-SA-1139, Pacific Northwest Laboratory, Richland, Washington, March 1967 .

10. W. J. Bailey to D. E. Christensen, Private communication. Pacific Northwest Laboratory, Richland, Washington. January 12,1968 . 
DISTRIBUTION

No. of

Copies

2

265

3

3

3

119

AEC Chicago Patent Group

G. H. Lee

R. K. Sharp

AEC Division of Technical Information Extension

AEC Richland Operations Office

C. L. Robinson

Technical Information Library (2)

Battelle Memorial Institute

Douglas United Nuclear

F. Bouse (3)

Battelle-Northwest

F. W. Albaugh

C. A. Bennett

C. L. Bennett

S. R. Bierman

C. L. Brown

W. L. Bunch

S. H. Bush

G. J. Busselman

J. J. Cadwe11

J. L. Carter

N. E. Carter

D. E. Christensen (5)

R. G. Clark

E. D. Clayton

G. M. Dalen

E. C. Davis

F. G. Dawson

D. R. de Halas

R. F. Dickerson

B. H. Duane

G. W. R. Endres

E. A. Eschbach

J. B. Edgar

E. A. Evans

J. R. Fishbaugher 
Battelle-Northwest (cont'd)

D. G. Foster

H. A. Fowler

J. J . Fuquay

A. G. Gibbs

D. W. Glasgow

V. W. Gustafson

C. E. Haines

R. J. $\mathrm{Ha} 11$

L. E. Hansen

G. E. Hanson

O. K. Har1ing

H. Harty

R. A. Harvey

C. M. Heeb

R. E. Heineman

H. L. Henry

R. J. Hoch

P. L. Hofmann

R. H. Holeman

U. P. Jenquin

R. D. Johnson

R. L. Junkins

G. J. Konzek

J. W. Kutcher

C. R. Lagergren

D. D. Lanning

J. H. Lauby

B. R. Leonard, Jr.

D. L. Lessor

W. R. Lewis

R. C. Liikala

C. W. Lindenmeier

E. P. Lippincott

W. W. Little

R. C. Lloyd

P. Loizzo

G. Manca

R. Martine11i

R. P. Matsen

D. D. Mat sumoto

G. C. Moore

E. S. Murphy (10)

D. F. Newman

R. E. Nightingale

T. J. Oakes 


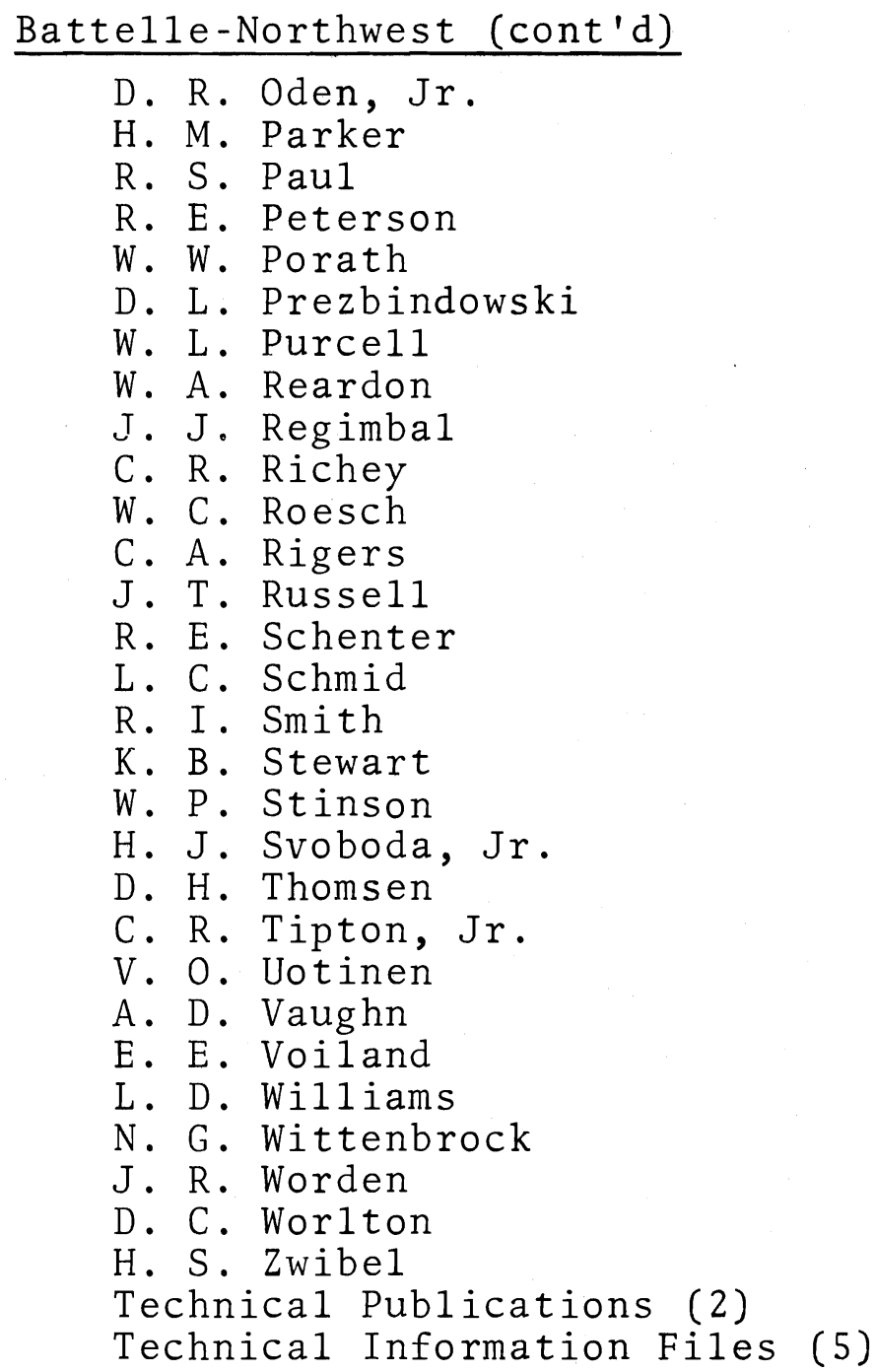




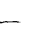

